\title{
Insights into the secondary fraction of the organic aerosol in a Mediterranean urban area: Marseille
}

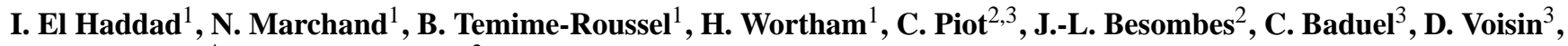 \\ A. Armengaud ${ }^{4}$, and J.-L. Jaffrezo ${ }^{3}$ \\ ${ }^{1}$ Universités d'Aix-Marseille-CNRS, UMR 6264: Laboratoire Chimie Provence, Equipe Instrumentation et Réactivité \\ Atmosphérique, 13331 Marseille, France \\ ${ }^{2}$ Laboratoire de Chimie Moléculaire et Environnement, Université Savoie-Polytech'Savoie, Chambéry, France \\ ${ }^{3}$ Université Joseph Fourier-Grenoble 1-CNRS, UMR 5183, Laboratoire de Glaciologie et Géophysique de l'Environnement, \\ 38402 Saint Martin d'Hères, France \\ ${ }^{4}$ Regional Network for Air Quality Monitoring (ATMO-PACA), 146 rue Paradis, 13006 Marseille, France
}

Received: 11 June 2010 - Published in Atmos. Chem. Phys. Discuss.: 1 November 2010

Revised: 24 February 2011 - Accepted: 28 February 2011 - Published: 7 March 2011

\begin{abstract}
A comprehensive aerosol characterization was conducted at Marseille during summer, including organic (OC) and elemental carbon (EC), major ionic species, radiocarbon $\left({ }^{14} \mathrm{C}\right.$ ), water-soluble OC and HULIS (HUmic LIke Substances), elemental composition and primary and secondary organic markers. This paper is the second paper of a two-part series that uses this dataset to investigate the sources of Organic Aerosol (OA). While the first paper investigates the primary sources (El Haddad et al., 2011), this second paper focuses on the secondary fraction of the organic aerosol.

In the context of overall OC mass balance, primary OC (POC) contributes on average for only $22 \%$ and was dominated by vehicular emissions accounting on average for $17 \%$ of OC. As a result, $78 \%$ of OC mass cannot be attributed to the major primary sources and remains un-apportioned. Radiocarbon measurements suggest that more than $70 \%$ of this fraction is of non-fossil origin, assigned predominantly to biogenic secondary organic carbon (BSOC). Therefore, contributions from three traditional BSOC precursors, isoprene, $\alpha$-pinene and $\beta$-caryophyllene, were considered. These were estimated using the ambient concentrations of Secondary Organic Aerosol (SOA) markers from each precursor and laboratory-derived marker mass fraction factors.

Secondary organic markers derived from isoprene photooxidation (ie: 2-methylglyceric acid and 2-methyltetrols) do not exhibit the same temporal trends. This variability was as-
\end{abstract}

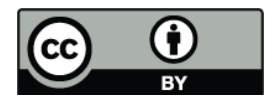

Correspondence to: I. El Haddad (imad.el-haddad@etu.univ-provence.fr) signed to the influence of $\mathrm{NO}_{\mathrm{x}}$ concentration on their formation pathways and to their potential decay by further processing in the atmosphere. The influence of changes in isoprene chemistry on assessment of isoprene SOC contribution was evaluated explicitly. The results suggest a 60 -fold variation between the different estimates computed using different isoprene SOC markers, implying that the available profiles do not reflect the actual isoprene SOC composition observed in Marseille.

Using the marker-based approach, the aggregate contribution from traditional BSOC was estimated at only $4.2 \%$ of total OC and was dominated by $\alpha$-pinene SOC accounting on average for $3.4 \%$ of OC. As a result, these estimates underpredict the inexplicably high loadings of OC. This underestimation can be associated with (1) uncertainties underlying the marker-based approach, (2) presence of other SOC precursors and (3) further processing of fresh SOC, as indicated by organosulfates $\left(\mathrm{RSO}_{4} \mathrm{H}\right)$ and HUmic LIke Substances (HULIS) measurements.

\section{Introduction}

It has been firmly established that organic aerosol (OA or organic carbon - OC) makes up for a major fraction of fine particulate matter $\left(\mathrm{PM}_{2.5}\right)$ in all region of the atmosphere. This fraction accounts roughly for half of the total $\mathrm{PM}_{2.5}$ dry mass (Kanakidou et al., 2005). Primary OA (POA) is directly emitted in the troposphere from anthropogenic sources (fossil fuel combustion or biomass burning) and natural sources

Published by Copernicus Publications on behalf of the European Geosciences Union. 
(e.g. vegetative detritus). Conversely, secondary OA (SOA) is formed in-situ in the atmosphere from the oxidation of biogenic or anthropogenic gas-phase precursors and subsequent partitioning of the less volatile products into the particle phase. The current number is that, on a global scale, SOA would represent around 60\% of the overall OA (Kanakidou et al., 2005). However, a recent global mass-balance estimation for the removal of volatile organic compounds (VOC) suggests that this number could under-predict SOA production rates by as much as an order of magnitude (Goldstein and Galbally, 2007). Recent field measurements in urban locations are also in support of a larger share, indicating that SOA is the dominant fraction of OA, with amounts considerably greater than model predictions (Heald et al., 2005; Volkamer et al., 2006). These observations point towards serious deficits in our current comprehension of the chemical nature of SOA and its formation mechanisms. The reasons for our insufficient understanding of SOA may result from a number of potential causes including missing SOA precursors, unconsidered SOA formation pathways (e.g. cloud processing or heterogeneous reactions) and inaccurate representation of OA evolution (e.g. volatilisation of POA and multigenerational chemistry) (Carlton et al., 2009 and references therein). Without an accurate knowledge of organic aerosol sources, development of effective air quality control strategies intended to mitigate PM adverse health, visibility and climate outcomes is hampered.

In response, research has currently targeted various approaches enabling the identification of both primary and secondary sources, together with the quantification of their relative strengths. One approach to investigate primary sources of OA is the chemical mass balance (CMB) modeling used in conjunction with measurements of organic molecular markers (Schauer and Cass, 2000; Schauer et al., 1996, 2002; Watson et al., 1998). This approach draws upon highly specific organic species to estimate the contribution of identified emissions from major primary sources, such as biomass burning or vehicular emissions. On this basis, an overall SOA mass can be derived, defined as the residual amount of organic carbon remaining after apportionment of primary sources. One shortcoming of this technique is that it is unable to determine the precursors contributing to the measured SOA. For policy purposes, the knowledge of SOA precursors is of the utmost importance, allowing reduction of SOA concentrations through the decrease of its main precursors.

Some recent work has led to an approach to estimate the contribution of SOA derived from traditional individual biogenic and anthropogenic sources (Kleindienst et al., 2007). Kleindienst and co-workers conducted smog chamber experiments in which individual Volatile Organic Compounds (VOC), including isoprene, $\alpha$-pinene, $\beta$-caryophyllene and toluene were irradiated in the presence of $\mathrm{NO}_{\mathrm{x}}$. These experiments enabled the determination of a set of organic markers specific to the aforementioned SOA precursors and provided the mass fraction of these markers (markers-to-SOA ratios).
Assuming that these mass fractions are relevant to typical atmospheric conditions, they were used to compute SOA contributions to ambient aerosol. This approach was applied in studies in several locations including urban areas in the US (Kleindienst et al., 2007; Lewandowski et al., 2008; Stone et al., 2009) and forested sites in Europe (Kourtchev et al., 2009; Kourtchev et al., 2008). The results provide evidence that SOA derived from some individual VOC can account for a significant fraction of the ambient OA (e.g. 20-70\% of OA - Kleindienst et al., 2007). However, this approach was typically applied on composite samples representative of extended periods of one week to one month (Lewandowski et al., 2008; Stone et al., 2009), preventing assessment of the impact of ambient conditions on SOA contributions. In addition, uncertainties associated with this method had never been considered explicitly.

This traditional split between SOA originating from light VOC and a non-reactive and non-volatile POA is currently becoming almost obsolete. Primary Organic Aerosol (POA) from biomass burning or motor vehicles includes a large fraction of semi-volatile species that may undergo photooxidation giving rise to low-volatility species that readily partition into particle phase, accounting for the majority of SOA (Donahue et al., 2006; Robinson et al., 2007). This process is supported by recent ambient measurements with Aerosol Mass Spectrometers (AMS) reporting high mass loadings of oxygenated organic aerosol (OOA) in young air masses downwind of anthropogenic sources (Volkamer et al., 2006). The oxidation chemistry of the main anthropogenic VOC that are traditionally incorporated in models as SOA precursors (i.e. light aromatics) cannot explain these observations, pointing to the contribution of SOA that originates from "untraditional" precursors. Laboratory experiments also support these observations, showing that photochemical aging of diluted emissions from diesel exhaust or biomass burning produces large amounts of SOA with physico-chemical properties (i.e. MS spectra and volatility) comparable with those of ambient SOA (Grieshop et al., 2009a, b; Robinson et al., 2007; Sage et al., 2008). Moreover, POA may also undergo further photo-oxidation reactions during atmospheric transport, which alter their original physico-chemical properties and give rise to a new fraction referred to as "oxidized primary organic aerosol" (OPOA). Such aging processes can equally affect the freshly formed secondary fraction of the OA, forming more oxidized and less volatile products (Alfarra et al., 2006; Camredon et al., 2010; Jimenez et al., 2009; Ng et al., 2006; Szmigielski et al., 2007). These processes transgress the traditional classification of the OA origins that considers a net split between primary and secondary fractions.

Investigations of the chemical nature of OA resulting from aging using molecular-level approaches are challenged by the lack of appropriate molecular markers and by the complexity of the OA composition containing tens of thousands of compounds (Hamilton et al., 2004; Hallquist et al., 2009). 
Still, considerable progress has been made in the determination of the chemical nature of bulk OA. For example, laboratory studies have provided clear evidence of the formation of organosulfate compounds and of high-molecular weight multifunctional products (HUmic LIke Substances, HULIS) upon the photo-oxidation of isoprene or monoterpene precursors (Surratt et al., 2008; Surratt et al., 2007). Such entities were actually measured in the ambient aerosol in several studies conducted in forested and remote areas (Feczko et al., 2007; Hallquist et al., 2009 and references therein). Investigations of the chemical mechanisms leading to the formation of these compounds are underway. Yet, current hypotheses are that these mechanisms occur in the particle phase or in aqueous phase (i.e. cloud water or deliquescent aerosol) (Hallquist et al., 2009 and references therein). The formation of such species can result in chemically complex mixtures that account for a significant fraction of ambient OA. For example, the aggregate contributions from organosulfates and HULIS represent up to $47 \%$ of the organic matter in the Kpuszta forested site (Kourtchev et al., 2009). Taken together, the results from the studies mentioned above reflect the complexity that faces accurate assessment of SOA, originating from a wide variety of precursors and resulting from several chemical formation pathways.

This paper is the second paper of a two-part series investigating the sources of organic aerosol during summertime in Marseille, a major French Mediterranean city. Results were obtained as part of the FORMES project during a 15day intensive field campaign. These two papers capitalize on off-line measurements including determination of organic molecular markers, metals, ${ }^{14} \mathrm{C}$, WSOC (water-soluble organic carbon), HULIS, OC/EC and major ions. This dataset offers the opportunity to provide a global insight into the organic aerosol characteristics and main sources. In the first paper entitled "Primary sources of $\mathrm{PM}_{2.5}$ particles in an industrial Mediterranean city, Marseille", a CMB analysis is used to investigate the primary sources of the OA. It shows that $78 \%$ of the OC mass cannot be attributed to the main primary sources, pointing out a critical need for the characterization of this large fraction mainly attributed to SOA. This second paper addresses thereby three specific objectives: (1) Characterizing the overall properties of SOA through the investigation of its intrinsic isotopic fingerprint inferred from radiocarbon measurements $\left({ }^{14} \mathrm{C}\right)$, the latter providing a direct separation between fossil and non-fossil sources. (2) Assessing, using the marker-based approach developed by Kleindienst et al. (2007), the contribution of traditional SOA derived from the main hydrocarbon precursors to the overall OC budget. The time-resolved dataset of molecular markers obtained in this study offers a unique opportunity to evaluate the dependence of such SOA contributions upon ambient conditions, and to critically address the uncertainties associated with these estimations. (3) Highlighting the potential contributions from other secondary sources to OA, including SOA derived from unconsidered precursors and from untra- ditional processes. The paper closes with a refined source apportionment of the $\mathrm{PM}_{2.5}$ mass including both primary and secondary fractions.

\section{Methods}

\subsection{Site description, sample collection and general conditions}

Sampling site description and general conditions are detailed in the companion paper and will only be briefly outlined here. Field measurement was conducted from 30 June to 14 July 2008, at an urban background site located in a downtown park "Cinq Avenues" ( $43^{\circ} 18^{\prime} 20^{\prime \prime} \mathrm{N}, 5^{\circ} 23^{\prime} 40^{\prime \prime}$ E, $64 \mathrm{~m}$ a.s.l.) in Marseille. $\mathrm{PM}_{2.5}$ collection was performed using high volume samplers (HiVol, Digitel DA80) operating at a flow rate of $30 \mathrm{~m}^{3} \mathrm{~h}^{-1}$. The samples were collected onto $150 \mathrm{~mm}$ diameter quartz fiber filters (Whatman QMA), pre-heated at $500^{\circ} \mathrm{C}$ during $3 \mathrm{~h}$. These samples were collected on a 12 -h basis (5:30 to 17:30 UT, and 17:30 to 05:30 UT, total number of 30 samples), enabling a relatively well time-resolved characterization of the particulate matter. Six field blank samples were also prepared following the same procedure. Ancillary data including $\mathrm{O}_{3}, \mathrm{SO}_{2}, \mathrm{NO}_{\mathrm{x}}$ and $\mathrm{PM}_{2.5} 15 \mathrm{~min}$-averaged concentrations were furthermore measured with the standard equipment of the Air Quality Monitoring Network (ATMOPACA), including a Tapered Element Oscillating Microbalance equipped with a Filter Dynamic Measurement System (TEOM-FDMS, Thermo Scientific) for $\mathrm{PM}_{2.5}$.

During this sampling period, several meteorological conditions were encountered, representative of those prevailing during summertime in Marseille. They can be classified as follows: (1) land and sea breeze cycles associated with intense photochemical and aging conditions were mainly encountered in the first days of the study, (2) southern winds associated with relatively clean air masses from the Mediterranean Sea ( $\mathrm{NO}_{\mathrm{x}}$ free conditions), and (3) a composition of land/sea breeze with light Mistral. Wind speeds in these cases were generally below $5 \mathrm{~m} \mathrm{~s}^{-1}$, except during some low pressure system episodes (with duration on the order of $24 \mathrm{~h}$ ) accompanied with Mistral. The overall period was characterized by moderate $\mathrm{PM}_{2.5}$ and $\mathrm{PM}_{10}$ levels (campaign average of 16 and $25 \mu \mathrm{g} \mathrm{m}^{-3}$, respectively). Ozone, $\mathrm{NO}_{\mathrm{x}}$ and $\mathrm{SO}_{2}$ average concentrations were 35,19 , and $2.5 \mathrm{ppb}$.

\subsection{OC/EC, WSOC, HULIS and major ion analysis}

The carbonaceous content of HiVol samples were analyzed for EC and OC using a Thermo-Optical Transmission method on a Sunset Lab analyzer (Jaffrezo et al., 2005; Birch and Cary, 1996), following the NIOSH protocol (Schmid et al., 2001). This method includes 4 temperature steps up to $870^{\circ} \mathrm{C}$ for the analysis of $\mathrm{OC}$ in $100 \% \mathrm{He}$, and 4 temperature steps up to $910^{\circ} \mathrm{C}$ for the analysis of $\mathrm{EC}$ in $98 \% \mathrm{He}+$ 
$2 \% \mathrm{O}_{2}$. At the end of each analysis an automatic internal calibration is performed by using a known volume and a fixed concentration of methane $\left(5 \% \mathrm{CH}_{4} ; 95 \% \mathrm{He}\right)$. Further, an external calibration is conducted 3 times per analyzing day with a sucrose standard $\left(42.07 \mu \mathrm{g} \mathrm{C} \mathrm{cm}{ }^{-2}\right)$.

Sample fractions of $11.34 \mathrm{~cm}^{2}$ were extracted into $15 \mathrm{~mL}$ of ultrapure water by 30 min short vortex agitation, in order to analyze major ionic species $\left(\mathrm{NH}_{4}^{+}, \mathrm{NO}_{3}^{-}, \mathrm{SO}_{4}^{2-}\right.$, and oxalate), water-soluble organic carbon (WSOC) and WaterSoluble HUmic LIke Substances (HULIS ${ }_{W S}$ ). Sample analysis of major ionic species was performed using ion chromatography, as described in Jaffrezo et al. (1998). The WSOC was quantified with an OI Analytical 700 TOC (total organic carbon) analyzer using persulphate oxidation at $100^{\circ} \mathrm{C}$ of the organic matter, followed by $\mathrm{CO}_{2}$ quantification with a non-dispersive infrared spectrophotometer (Jaffrezo et al., 1998).

Water-soluble HULIS (HULIS ${ }_{W S}$ ) analysis was performed on the water extracts following the method described in Baduel et al. $(2009,2010)$. The HULIS ${ }_{W S}$ fraction is extracted from the other WSOC by adsorption onto DEAE resin, and its quantification is performed with a TOC analyser. The samples are loaded on a DEAE column (GE Healthcare ${ }^{\circledR}$, HiTrapTM DEAE FF, $0.7 \mathrm{~cm}$ ID $\times 2.5 \mathrm{~cm}$ length) without any preacidification. After this concentration step, neutral compounds, mono- and di-carboxylic acids are eluted with $12 \mathrm{~mL}$ of a solution of $\mathrm{NaOH} 0.04 \mathrm{M}$. Finally, the fraction including polycharged compounds (HULIS $\mathrm{WS}_{\mathrm{S}}$ ) is eluted using a high ionic strength solution of $\mathrm{NaCl} 1 \mathrm{M}$. This poly-carboxylic acid fraction is collected and measured for its carbon content is quantified as mentioned above. Computation of HULIS ${ }_{W S}$ concentrations in the atmosphere takes into account the extraction efficiencies of the DEAE resin, as well as field blank concentrations (Baduel, 2010; Baduel et al., 2009, 2010). HULIS ${ }_{W S}$ concentrations determined in field blanks never accounted for more than $3 \%$ of HULIS ${ }_{W S}$ in real samples of this series.

\section{$2.3{ }^{14} \mathrm{C}$ analysis}

Radiocarbon measurements were conducted on HiVol quartz filter fractions $\left(\sim 40 \mathrm{~cm}^{2}\right)$ using ARTEMIS Accelerator Mass Spectrometry, at Saclay (CNRS-CEA-IRD-IRSN, France). Each sample is first packed into a prefired quartz tube containing $\mathrm{CuO}$ and $\mathrm{Ag}$ powder. The tube is combusted at $850^{\circ} \mathrm{C}$ in a muffle furnace for $4 \mathrm{~h}$. Carbon dioxide $\left(\mathrm{CO}_{2}\right)$ is collected and purified before its conversion into graphite by hydrogen reduction at $600{ }^{\circ} \mathrm{C}$ using $\mathrm{Fe}$ catalyst. The modern fraction $\left(f_{\mathrm{m}}\right)$ is determined as the ratio of ${ }^{14} \mathrm{C} /{ }^{12} \mathrm{C}$ in aerosol sample to ${ }^{14} \mathrm{C} /{ }^{12} \mathrm{C}$ in the NBS Oxalic Acid standard (NIST-SRM-4990B). In order to account for the thermonuclear weapon tests of the late 1950s and early 1960s that increased the radiocarbon content of the atmosphere (Levin et al., 1985), the modern fraction $\left(f_{\mathrm{m}}\right)$ is divided by a ratio of 1.1 to obtain the real contemporary fraction $\left(f_{\mathrm{C}}\right)$ (Levin and Hesshaimer, 2000). This corrected value is subsequently subtracted from one to obtain the fossil fraction $\left(f_{\mathrm{f}}\right)$.

\subsection{Characterization of SOA markers}

Quantitative analysis of SOA markers was performed by an Electron Ionisation GC/MS (EI-GC/MS) approach adapted from the technique employed by El Haddad et al. (2009, 2011) to analyse primary organic markers. Prior to extraction, filters are spiked with known amounts of two isotope-labelled standards: tetracosane-d50 and cholesterold6. Organic species are extracted from the filters with a dichloromethane/acetone mixture (1/1 v:v) using an accelerated pressurized solvent extraction device at $100^{\circ} \mathrm{C}$ and 100 bar (ASE, Dionex 300). Extracts are then reduced to a volume of $500 \mu \mathrm{L}$ using a Turbo Vap II concentrator. During the concentration process, $1 \mathrm{~mL}$ of acetonitrile is added to the extracts in order to obtain a $500 \mu \mathrm{L}$ extract in acetonitrile, acetonitrile being less volatile than the mixture dichloromethane/acetone (1:1). A $100 \mu \mathrm{L}$ fraction of the extract is subjected to silylation derivatization for $2 \mathrm{~h}$ at $70^{\circ} \mathrm{C}$ using $100 \mu \mathrm{L}$ of N,O-bis(trimethylsilyl)-trifluoroacetamide (BSTFA) with $10 \%$ trimethyl-chlorosilane which convert hydroxyl groups to trimethylsilyl groups (TMS). Aliquots of $2 \mu \mathrm{L}$ are then immediately analysed by GC/MS using the same conditions as detailed in El Haddad et al. (2009). The GC/MS system consists in a Thermo Trace GC chromatograph interfaced to a Polaris Q ion trap mass spectrometer fitted with an external ionisation source $(70 \mathrm{eV})$. The chromatographic separation is accomplished on a TR-5MS capillary column (Thermo Electron, $30 \mathrm{~m} \times 0.25 \mathrm{~mm}$ i.d. $\times 0.25 \mu \mathrm{m}$ film thickness). Data is recorded in the full scan mode in the mass range $m / z$ 50-500. Field blank filters are also treated with the same procedure (El Haddad et al, 2011). None of the target compounds are detected in these field blanks.

In the absence of native standards for most SOA markers, their identification is based on the interpretation of their EI mass spectrum and comparison with previously reported MS data for these compounds (Claeys et al., 2004a, b, 2007; Jaoui et al., 2005; Kleindienst et al., 2007; Kourtchev et al., 2009). Table 1 summarizes the interpretation of EI mass spectra of SOA markers resulting from isoprene, $\alpha$-pinene and $\beta$-caryophyllene photo-oxidation. EI mass spectra are also presented in Figs. 1 and S1 in the Supplement, for $\alpha$ pinene and isoprene oxidation products, respectively.

The analysis of EI spectra of TMS derivatives involves recognition of characteristic ions resulting from particular fragmentation mechanisms. For example, the molecular ions of TMS derivatives often lose a methyl radical which yields an abundant fragment at $[\mathrm{M}-15]^{+}$. This fragment generally allows to infer the derivative molecular weight (MD), which corresponds to $\mathrm{MD}=\mathrm{MW}+72 \mathrm{n}(\mathrm{OH})$, where $\mathrm{MW}$ is the compound molecular weight and $\mathrm{n}(\mathrm{OH})$ is the total number of derivatised $(-\mathrm{OH})$ and $(-\mathrm{COOH})$. Characteristic fragments of silylated mono-carboxylic acids include $\mathrm{m} / z, 117$ 
Table 1. EI MS response of SOA markers TMS derivatives. Between brackets are the relative intensities of the fragments. In bold character are the ions selected for the identification and the quantification of the organic compounds.

\begin{tabular}{|c|c|c|c|c|c|c|c|c|c|c|c|c|c|c|c|}
\hline \multirow[b]{2}{*}{ products } & \multirow[b]{2}{*}{$\begin{array}{l}\text { Ret. time } \\
\text { (min) }\end{array}$} & \multirow[b]{2}{*}{$\begin{array}{l}\text { Comps. } \\
\mathrm{MW} \\
\left(\mathrm{g} \mathrm{mol}^{-1}\right)\end{array}$} & \multirow[b]{2}{*}{$\begin{array}{l}\text { TMS } \\
\text { Deriv. MW } \\
\left(\mathrm{g} \mathrm{mol}^{-1}\right)\end{array}$} & \multicolumn{12}{|c|}{ Derivatives major ions } \\
\hline & & & & $\mathrm{M}-\mathrm{CH}_{3} \bullet$ & $\begin{array}{l}\mathrm{M}-\mathrm{CO} \\
-\mathrm{CH}_{3} \bullet\end{array}$ & $\begin{array}{l}\text { M } \\
-\mathrm{TMSOH}^{-} \\
-\mathrm{CH}_{3} \bullet\end{array}$ & M-COOSiMe & $\begin{array}{l}\mathrm{M}- \\
\mathrm{CH}_{2} \mathrm{COOSiMe}_{3} \bullet\end{array}$ & $\begin{array}{l}\text { M- } \\
\text { TMSOH- } \\
\text { CO } \\
-\mathrm{CH}_{3} \bullet\end{array}$ & $\begin{array}{l}\mathrm{M} \\
-\mathrm{TMSOH} \\
-2 \mathrm{CO} \\
-\mathrm{CH}_{3} \bullet\end{array}$ & $\begin{array}{l}\mathrm{M}-\mathrm{TMSOH} \\
-\left(\mathrm{CH}_{3}\right)_{2} \mathrm{SiO} \\
-\mathrm{CH}_{3} \bullet\end{array}$ & $m / z 117^{\dagger}$ & $m / z 129^{\dagger}$ & $m / z 147^{\dagger}$ & $m / z 149^{\dagger}$ \\
\hline $2-\mathrm{MGA}^{\mathrm{b}+\frac{1}{*}}$ & 14.20 & 120 & 336 & $\begin{array}{l}m / z 321 \\
\text { (4) }\end{array}$ & $\begin{array}{l}m / z 293 \\
(11)\end{array}$ & - & $\begin{array}{l}m / z 219 \\
(81)\end{array}$ & - & $\begin{array}{l}m / z 203 \\
(52)\end{array}$ & - & & 16 & 48 & 100 & 38 \\
\hline 2-MT1 $1^{\mathrm{c}}$ & 18.55 & 136 & 424 & - & - & - & - & - & - & - & - & 40 & 58 & 48 & - \\
\hline $2-\mathrm{MT}^{\mathrm{c}}{ }^{\mathrm{*}}$ & 18.92 & 136 & 424 & - & - & - & - & - & - & - & - & 40 & 58 & 48 & - \\
\hline $\mathrm{Al}^{\mathrm{d} * \frac{*}{t}}$ & 19.68 & 148 & 364 & $\begin{array}{l}m / z 349 \\
(16)\end{array}$ & - & $\begin{array}{l}m / z 259 \\
(23)\end{array}$ & - & - & $\begin{array}{l}m / z 231 \\
(31)\end{array}$ & - & $\begin{array}{l}\boldsymbol{m} / \boldsymbol{z} \mathbf{1 8 5} \\
(73)\end{array}$ & - & - & 100 & 32 \\
\hline $\mathrm{A} 2^{\mathrm{d} \S}$ & 20.28 & 172 & 316 & $\begin{array}{l}m / z 301 \\
\text { (4) }\end{array}$ & - & - & - & - & - & - & - & - & 22 & 28 & - \\
\hline $\mathrm{A}^{*}{ }^{\mathrm{d}}$ & 20.36 & 176 & 392 & $\begin{array}{l}\boldsymbol{m} / \boldsymbol{z} 377 \\
(19)\end{array}$ & - & $\begin{array}{l}m / z 287 \\
(19)\end{array}$ & - & - & $\begin{array}{l}m / z 259 \\
(13)\end{array}$ & - & $\begin{array}{l}\boldsymbol{m} / \boldsymbol{z} \mathbf{2 1 3} \\
(55)\end{array}$ & - & - & 100 & 35 \\
\hline $\mathrm{A} 4^{\mathrm{d} \$ \vec{े}}$ & 20.58 & 174 & 318 & $\begin{array}{l}m / z 303 \\
(14)\end{array}$ & - & - & - & $\begin{array}{l}m / z 187 \\
(28)\end{array}$ & $\begin{array}{l}m / z 185 \\
(46)\end{array}$ & $\begin{array}{l}\boldsymbol{m} / z \mathbf{z} 157 \\
(82)\end{array}$ & - & - & 28 & 38 & 18 \\
\hline $\mathrm{A} 5^{\mathrm{d} \$ \grave{~}}$ & 22.63 & 188 & 332 & $\begin{array}{l}m / z 317 \\
(16)\end{array}$ & - & - & - & $\begin{array}{l}m / z 201 \\
(12)\end{array}$ & $\begin{array}{l}m / z 199 \\
(23)\end{array}$ & - & - & - & - & 49 & 21 \\
\hline $\mathrm{A}^{\mathrm{d} \mathrm{d}^{\S \stackrel{7}{*}}}$ & 22.72 & 174 & 318 & $\begin{array}{l}m / z 303 \\
(20)\end{array}$ & $\begin{array}{l}m / z 275 \\
(18)\end{array}$ & $\begin{array}{l}m / z 213 \\
(34)\end{array}$ & $\begin{array}{l}m / z 201 \\
(9)\end{array}$ & - & $\begin{array}{l}m / z 185 \\
(74)\end{array}$ & - & - & - & - & 28 & 16 \\
\hline $\mathrm{A} 7^{\mathrm{d}+\#}$ & 22.99 & 204 & 420 & $\begin{array}{l}m / z 405 \\
(30)\end{array}$ & - & - & - & - & $\begin{array}{l}m / z 287 \\
(46)\end{array}$ & - & - & - & - & 100 & 34 \\
\hline PNA $^{\mathrm{a}}$ & 19.05 & 184 & 256 & - & - & - & - & - & - & - & - & - & - & - & - \\
\hline $\mathrm{PA}^{\mathrm{a} \frac{\tilde{t}}{\hbar}}$ & 21.58 & 182 & 330 & $\begin{array}{l}m / z \mathbf{z 1 5} \\
(13)\end{array}$ & - & - & - & - & - & - & - & - & 64 & - & - \\
\hline $\mathrm{C}^{\mathrm{e} \neq}$ & 26.95 & 254 & 398 & $\begin{array}{l}\boldsymbol{m} / \boldsymbol{z} 383 \\
(31)\end{array}$ & - & - & - & - & - & - & - & - & - & 100 & - \\
\hline
\end{tabular}

Isoprene oxidation products: 2-MGA=2-methylglyceric acid; 2-MT1=2-Methylthreitol; 2-MT2=2-Methylerythritol. $\alpha$-Pinene oxidation products: $\quad$ A1=3-hydroxyglutaric acid; A2=3-(2-hydroxyethyl)-2,2-dimethylcyclobutane carboxylic acid; A3=3-hydroxy-4,4-dimethylglutaric acid; A4=3-acetylglutaric acid; A5=3-acetyladipic acid; A6=3isopropylglutaric acid; $\mathrm{A} 7=3$-methyl-1,2,3-butanetricarboxylic; $\mathrm{PNA}=$ pinonic acid; $\mathrm{PA}=$ pinic acid. $\boldsymbol{\beta}$-Caryophyllene oxidation product: $\mathrm{C}=\beta$-caryophyllenic acid.

Identification notes: ${ }^{a}$ Characterized by analysis of authentic standards. $§$ Structures proposed by Jaoui et al. (2005) upon chemical ionisation-GC/MS analysis. * Identified by Claeys et al. (2007) by EI-GC/MS analysis of synthesized authentic standards. ${ }^{+}$Identified by Szmigielski et al. (2007). Quantification notes: ${ }^{a}$ Quantified by analysis of authentic standards. ${ }^{\mathrm{b}},{ }^{\mathrm{c}},{ }^{\mathrm{d}}$ and ${ }^{\mathrm{e}}$ : quantification of the organic compounds is based on the response factors of surrogate standards: ${ }^{\mathrm{b}}$ glyceric acid (major ions: 307 (5), 217 (7) 189 (61)), ${ }^{\mathrm{c}}$ threitol (major ions: $m / z 320$ (9), $m / z 307$ (14), $m / z 293$ (10), $m / z 217$ (98), $m / z 205$ (20), $m / z \quad 189$ (17), $m / z \quad 147$ (100), $m / z 117$ (18)), ${ }^{\mathrm{d}}$ malic acid (major ions: $m / z 335$ (6 ), $m / z 307$ (26), $m / z 245(19), m / z 223(30), m / z 217(10), m / z 189(16))$ and ${ }^{e}$ pinic acid. Response factors [arbitrary units] of glyceric acid, threitol, malic acid, pinonic acid and pinic acid are $0.95,1.6,1.3,0.81$ and 0.71 , respectively.

MS spectra notes: ${ }^{\dagger} m / z 117\left[\mathrm{OCO}-\mathrm{Si}\left(\mathrm{CH}_{3}\right)_{3}\right]^{+} ; m / z 129\left[\mathrm{CH}_{2}=\mathrm{CH}-\mathrm{CO}-\mathrm{O}=\mathrm{Si}\left(\mathrm{CH}_{3}\right)_{2}\right]^{+} ; m / z 147\left[\left(\mathrm{CH}_{3}\right)_{3} \mathrm{Si}-\mathrm{O}=\mathrm{Si}\left(\mathrm{CH}_{3}\right)_{2}\right]^{+} ; m / z 149\left[\left(\mathrm{CH}_{3}\right)_{2} \mathrm{Si}=\mathrm{O}-\mathrm{Si}(\mathrm{CH})_{2}-\mathrm{OH}\right]^{+} ; m / z 217$ $\left[\mathrm{CH} 2=\mathrm{CH}-\mathrm{COO}-\left(\mathrm{Si}\left(\mathrm{CH}_{3}\right)_{3}\right)_{2}\right]^{+} \ddagger$ present other major ions:

I - 2-MGA: $\left.m / z \quad 189\left[\mathrm{M}-\mathrm{CH}_{4}-\mathrm{CO}-\mathrm{CH}_{2} \mathrm{OSi}\left(\mathrm{CH}_{3}\right)_{3}^{\bullet}\right]^{+}(18) \mathrm{II}-2-\mathrm{MT}: m / z 277\left[\mathrm{M}-\mathrm{CH}_{4}-\mathrm{CO}-\mathrm{CH}_{2} \mathrm{OSi}_{(\mathrm{CH}}\right)_{3}^{\bullet}\right]^{+}(18) ; \boldsymbol{m} / z \mathbf{2 1 9}\left[\left(\mathrm{CH}_{3}\right)_{3} \mathrm{Si}-\mathrm{OCH} \mathrm{C}_{2}\left(\mathrm{CH}_{3}\right)=\mathrm{O}-\mathrm{Si}\left(\mathrm{CH}_{3}\right)_{3}\right]^{+}$

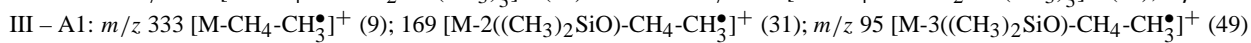

$\mathrm{IV}-\mathrm{A} 4: \boldsymbol{m} / \boldsymbol{z} 111$ [M-TMSOH- $\left.\left(\mathrm{CH}_{3}\right)_{2} \mathrm{SiO}-\mathrm{CO}-\mathrm{CH}_{3}^{\bullet}\right]^{+}(100)$

$\mathrm{V}-\mathrm{A} 5: \boldsymbol{m} / \boldsymbol{z} 125\left[\mathrm{M}-\mathrm{TMSOH}-\left(\mathrm{CH}_{3}\right)_{2} \mathrm{SiO}-\mathrm{CO}-\mathrm{CH}_{3}^{\bullet}\right]^{+}(51)$

$\mathrm{VI}$ - A6: $m / z 259\left[\mathrm{M}-\mathrm{CH}_{4}-\mathrm{CO}-\mathrm{CH}_{3}^{\bullet}\right]^{+}(18) ; \boldsymbol{m} / z \mathbf{2 2 9}\left[\mathrm{M}-\left(\mathrm{CH}_{3}\right)_{2} \mathrm{SiO}_{-} \mathrm{CH}_{3}^{\bullet}\right]^{+}(54) ; \boldsymbol{m} / z \mathbf{~} 173\left[\mathrm{M}-\mathrm{CO}-\mathrm{COOSi}\left(\mathrm{CH}_{3}\right)_{3}^{\bullet}\right]^{+}(51) ; \boldsymbol{m} / z \mathbf{1 7 3}\left[\mathrm{M}-\mathrm{C}_{3} \mathrm{H}_{6}-\mathrm{COOSi}(\mathrm{CH} 3)_{3}^{\bullet}\right]^{+}(51) ; \boldsymbol{m} / z \mathbf{1 1 1}$ $\left[\mathrm{M}-\mathrm{TMSOH}-\left(\mathrm{CH}_{3}\right)_{2} \mathrm{SiO}-\mathrm{CO}-\mathrm{CH}_{3}^{\bullet}\right]^{+}(100)$

VII - A7: $m / z 333\left[\mathrm{M}-\mathrm{C}_{3} \mathrm{H}_{8}-\mathrm{CO}-\mathrm{CH}_{3}^{\bullet}\right]^{+}(9) ; m / z 245\left[\mathrm{M}-\mathrm{C}_{3} \mathrm{H}_{6}-\mathrm{TMSOH}-\mathrm{CO}-\mathrm{CH}_{3}^{\bullet}\right]^{+}(24) ; m / z 243$ [M-C $\left.{ }_{3} \mathrm{H}_{8}-\mathrm{TMSOH}-\mathrm{CO}-\mathrm{CH}\right]^{+}(18) ; \boldsymbol{m} / z$ 213 [M-TMSOH$-(\mathrm{CH})_{2} \mathrm{SiO}-$

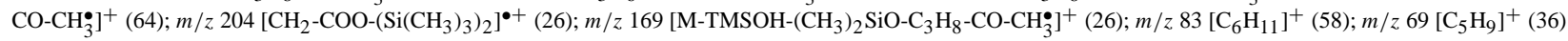

VIII - PNA: $\boldsymbol{m} / \boldsymbol{z} 171\left[\mathrm{M}-\mathrm{CH}_{2} \mathrm{CHCOCH}_{3}-\mathrm{CH}_{3}^{\bullet}\right]^{+}(32) ; m / z$ $97\left[\mathrm{M}-\mathrm{CH}_{2} \mathrm{CHCOCH}_{3}-\left(\mathrm{CH}_{3}\right)_{2} \mathrm{SiO}-\mathrm{CH}_{3}^{\bullet}\right]^{+}(13)$

IX - PA: $\left.m / z 240[\mathrm{M}-\mathrm{TMSOH}]^{\bullet+}(20) ; \boldsymbol{m} / z \mathbf{~} 196\left[\mathrm{M}-\mathrm{TMSOH}-\mathrm{CO}-\mathrm{CH}_{4}\right]^{\bullet+}(11) ; \mathrm{m} / z 171\left[\mathrm{M}-\mathrm{CH}_{2} \mathrm{CHCOOSi}\left(\mathrm{CH}_{3}\right)_{3}-\mathrm{CH}_{3}^{\bullet}\right]^{+}(58) ;\right) ; m / z 157\left[\mathrm{M}-\mathrm{CH} \mathrm{CHCH}_{2} \mathrm{COOSi}_{2}\left(\mathrm{CH}_{3}\right)_{3}-\right.$ $\left.\mathrm{CH}_{3}^{\bullet}\right]^{+}(34) ; m / z 83\left[\mathrm{M}-\mathrm{CH}_{2} \mathrm{CHCH}_{2} \mathrm{COOSi}\left(\mathrm{CH}_{3}\right)_{3}-\left(\mathrm{CH}_{3}\right)_{2} \mathrm{SiO}-\mathrm{CH}_{3}^{\bullet}\right]^{+}$(26)

$\mathrm{X}-\mathrm{C}: \boldsymbol{m} / z 398\left[\mathrm{M}^{\bullet}\right]^{+}(7) ; \boldsymbol{m} / z 309\left[\mathrm{M}-\left(\mathrm{CH}_{3}\right)_{2} \mathrm{SiO}-\mathrm{CH}_{3}^{\bullet}\right]^{+}(10)$

that arises from $\alpha$-cleavage and $m / z 129$ resulting from $\gamma$ cleavage and subsequent methane loss. In contrast, derivatives of compounds bearing alcoholic moieties generally exhibit a fragment ion at $m / z 103\left(\left[\mathrm{CH}_{2}=\mathrm{O}-\mathrm{SiMe}_{3}\right]^{+}\right)$(Rontani and Aubert, 2004). However, the TMS-derivatisation technique does not allow to distinguish between alcoholic and carboxylic hydroxyl groups in the same molecule (Jaoui et al., 2005), which are present in some of the multifunctional molecular markers under study. The presence of several TMS groups in the same compound can undergo uncharacteristic EI fragmentations involving the interaction between the groups. These interactions primarily occur through five- to eight-membered ring transition (Rontani and Aubert, 2004). Thus, they are influenced by the compound chain length and enhanced in the case of organic compounds with four to eight carbon numbers. Fragment ions resulting from these interactions include, among others, $m / z$ 147, $m / z$ 149, $[\mathrm{M}-31]^{+},[\mathrm{M}-105]^{+}$and $[\mathrm{M}-131]^{+}$. Nevertheless, a constant fragmentation pattern characteristic of the functional groups within the target molecules cannot be established. This complicates the EI-MS data interpretation and special care has to be taken when assigning the molecular structures in such cases. 

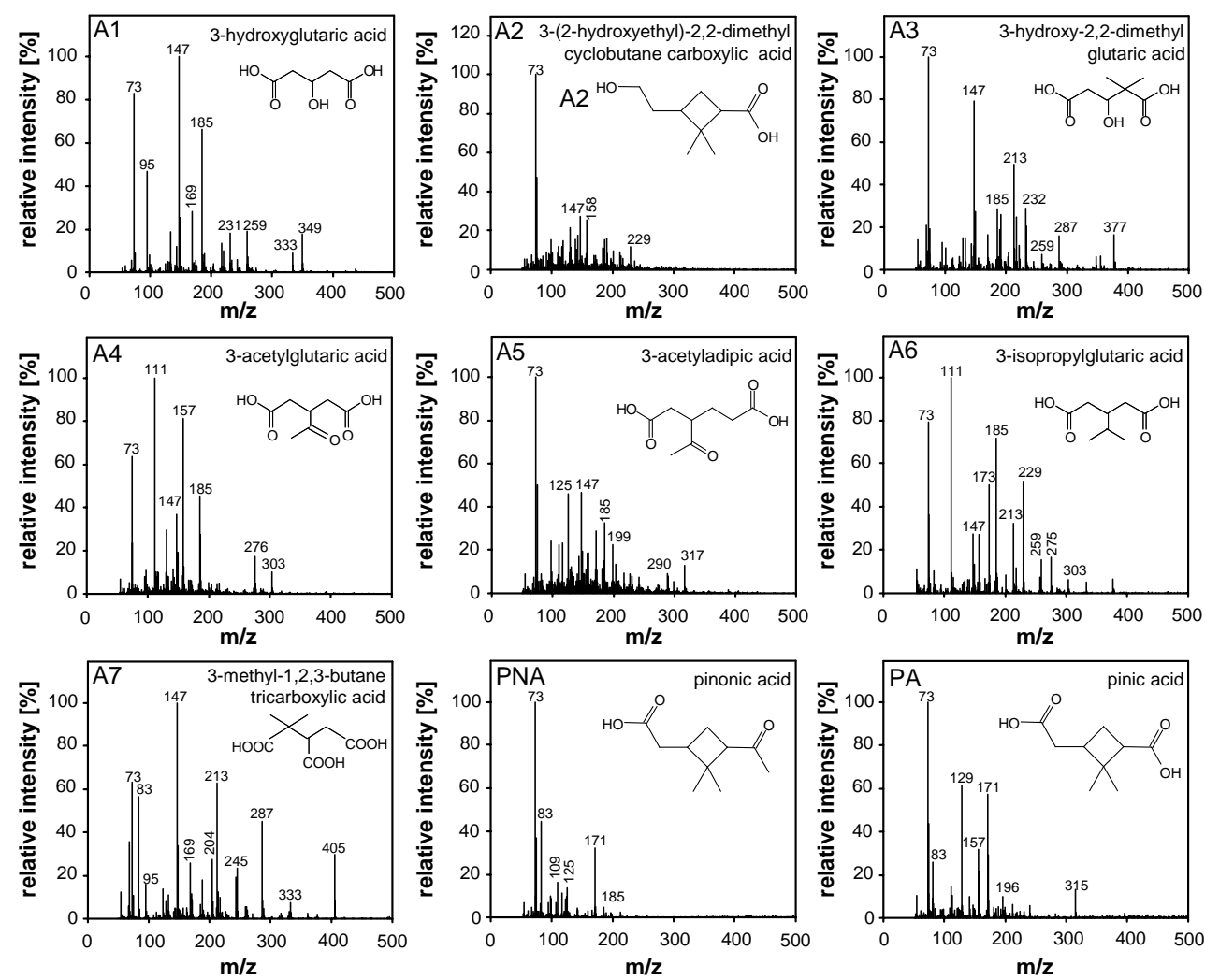

Fig. 1. EI mass spectra for TMS derivatives of $\alpha$-pinene SOC markers, for which the chemical structures are also shown. Mass spectra analysis are reported in Table 1 and discussed in the text.

On the basis of the MS spectra interpretation, 13 SOA markers have been identified (Table 1): three compounds previously identified as isoprene SOA markers are detected, including 2-methylglyceric acid (2-MGA) and the two 2methyltetrols diastereoisomers: 2-methylthreitol (2-MT1) and 2-methylerythritol (2-MT2). These markers were initially detected in ambient $\mathrm{PM}_{2.5}$ collected from the Amazonian rainforest (Claeys et al., 2004a) and subsequently used to trace the photo-oxidation of isoprene in the atmosphere (Kourtchev et al., 2009; Kourtchev et al., 2008; Stone et al., 2009 and references therein).

In addition to pinic (PA) and pinonic (PNA) acid for which authentic standards are available, seven multifunctional markers of $\alpha$-pinene SOA are identified (A1-A7) in our samples. 3-hydroxyglutaric acid (A1) and 3-hydroxy4,4-dimethylglutaric acid (A3) are identified by comparing their spectra with those reported in Claeys et al. (2007). The latter study identified these two compounds using EIMS analysis of synthesised standards. The $\mathrm{C}_{8}$-tricarboxilic acid (A7) is identified by comparing its spectra with that reported in Szmigielski et al. (2007). This compound was at first erroneously assigned to 3-carboxyheptanoic acid (Jaoui et al., 2005) and to 2-hydroxy-4-isopropyladipic acid, based on EI mass spectra of synthesised isomeric compound (Claeys et al., 2007). However Szmigielski et al. (2007) confirmed its structure as 3-methyl-1,2,3-butanetricarboxylic by comparing its gas and liquid chromatographic behaviors and MS characteristics with those of a synthesized reference (Szmigielski et al., 2007). 3-(2-hydroxyethyl)-2,2dimethylcyclobutane carboxylic acid (A2), 3-acetylglutaric acid (A4), 3-acetyladipic acid (A5), and 3-isopropylglutaric acid (A6) were tentatively identified by examining their EIMS spectra fragmentation pattern (Table 1). The structures of these compounds were reported in Jaoui et al. (2005), in a study that used a multiple derivatisation method in conjunction with Chemical Ionisation MS (CI-MS) and EI-MS analysis for the identification of monoterpene SOA markers. It should be noted that compounds A1 to A7 were also observed in laboratory irradiation experiments of other terpenes ( $\beta$-pinene and d-limonene) in presence of $\mathrm{NO}_{\mathrm{x}}$ (Jaoui et al., $2005)$ and are therefore not fully specific of $\alpha$-pinene reaction products. Finally, $\beta$-caryophyllinic (C) acid is observed in our samples and identified as a marker for $\beta$-caryophyllene SOA (Jaoui et al., 2007).

Quantification of SOA markers is based on the responses of their predominant MS fragments (in bold character, Table 1). The quantification of PA and PNA is achieved using their authentic standards (Table 1). The other SOA markers, for which no authentic standard are available, are quantified using the response factor of compounds with analogous 
chemical structures, specified in the footnotes to Table 1. Glyceric acid and threitol were used for the quantification of 2-methylglyceric acid and 2-methyltetrols, respectively. Compounds A1-A7 derived from $\alpha$-pinene oxidation were quantified using the response factor of malic acid. Finally, pinic acid was used as a surrogate standard for the quantification of $\beta$-caryophyllinic acid. The quantification approach applied here is equivalent to those applied in previous molecular markers/SOA apportionment studies (Fu et al., 2009; Stone et al., 2009) but different from that applied in the study by Kliendienst et al. (2007) where marker-to-SOC ratios were determined. Consequently, special care has to be considered when comparing concentration results derived from studies that use different surrogate standards. Systematic biases associated with the use of surrogate calibration is estimated to be within a factor of 2 , based on the differences observed among the response factors of the authentic standards (Table 1). Relative standard deviation of the concentrations based on duplicate analysis is between 5 and $15 \%$.

\subsection{Measurements of isoprene and its gas phase oxidation products}

In addition to aerosol sampling, HS-PTRMS (High Sensitivity Proton Transfer Reaction Mass Spectrometer, Ionicon Analytic, (Lindinger et al., 1998)) was deployed during our field study in order to quantify VOC and oxygenated VOC with a special focus on isoprene and its gas-phase oxidation products. Briefly, HS-PTRMS consists of a discharge ion source that produces $\mathrm{H}_{3} \mathrm{O}^{+}$ions, a drift-tube reactor, in which the proton-transfer reactions between $\mathrm{H}_{3} \mathrm{O}^{+}$and VOC take place, and a quadrupole mass spectrometer that detects the resulting product ions. In general, the product ion of a given VOC having a molecular mass $\mathrm{M}$ will be detected by the HS-PTRMS at $\mathrm{M}+1 \mathrm{amu}$, corresponding to $\mathrm{VOCH}^{+}$. Because of the quadrupole resolution, VOC isomers cannot be distinguished. The quantification of these VOC is based on proton-transfer rate coefficients that were computed by Zhao and Zhang using quantum chemical methods (Zhao and Zhang, 2004).

HS-PTRMS measurements of isoprene detected at $m / z, 69$ have been inter-compared in a great number of studies (de Gouw and Warneke, 2007 and references therein). Regardless of the presence of multiple interferences (i.e. methylbutanals, pentenols and furans), HS-PTRMS measurements of isoprene have compared well against alternative techniques (agreement within 20\%) in a variety of conditions, including those impacted by industrial emissions (Kuster et al., 2004), fresh and aged urban emissions (de Gouw et al., 2003), and aged forest fire emissions (de Gouw and Warneke, 2007). Methylvinylketone (MVK) and methacrolein (MACR) are derived from the atmospheric oxidation of isoprene, and both are detected at $m / z$ 71. They cannot be separated by HS-PTRMS, but inter-comparisons have shown that the HSPTRMS measurement can be regarded as a sum measure- ment (de Gouw and Warneke, 2007 and references therein). As in the case of isoprene, HS-PTRMS measurements of MVK and MACR have compared well versus alternative techniques (de Gouw and Warneke, 2007 and references therein).

Temporal variation of isoprene $(m / z 69)$ and its oxidation products, MACR+MVK $(m / z, 71)$ during our study are reported in Fig. S2, in the supporting information. Isoprene concentrations show strong diurnal variations that correlate well with ambient temperature (see Fig. S2, first panel). Such observation implies that biogenic sources of isoprene that predominate during daytime largely govern those of its potential interfering compounds. Concentrations of MACR+MVK follow a trend similar to that of isoprene, with higher concentrations during daytime (Fig. S2, second panel). Consequently, HS-PTRMS $m / z 69$ and $m / z 71$ attributions to isoprene and MVK+MACR, respectively, can be inferred with a good level of confidence.

\section{Contemporary Secondary Organic Carbon (SOC)}

In the companion paper (El Haddad et al., 2011), a CMB analysis is performed to estimate the contribution from primary sources. The model considers the major anthropogenic and biogenic sources including vehicular emissions, industrial emissions, biomass burning, natural gas combustion, and vegetative detritus. The aggregate contributions from these sources account for $22 \%$ on average of the overall OC mass balance. From this CMB source apportionment exercise, an upper limit of secondary OC can be inferred by equating it to the difference between the total OC ambient concentration and the sum of the modeled primary source contributions. This secondary OC can thus be estimated to contribute to $78 \%$ of the total OC. It shall be noted that CMB approach implicitly considers the conservation of primary organic markers-to-OC ratios from the sources to the receptor site. From a conceptual point of view, CMB approach apportions the whole mass of carbon emitted by primary sources regardless of its chemical state (reacted or un-reacted). Consequently, SOC is treated by the CMB approach as an increase of the carbon mass caused by the oxidation processes of volatile and semi-volatile organic compounds.

In the companion paper, we discuss the photochemical decay of molecular markers such as hopane homologues, showing that such decay does not significantly alter the CMB estimates of the total primary OC (El Haddad et al., 2011). It is also shown that sampling artifacts and unaccounted primary sources only appear to marginally influence the amount of un-apportioned OC. Therefore, this significant amount of un-apportioned OC (i.e. $78 \%$ of the total OC on average) is mostly attributed to secondary organic carbon. This assumption is supported by the good correlation between unapportioned OC and the water soluble OC (WSOC) $\left(R^{2}=\right.$ $0.87, n=25)$, the latter being commonly associated with 


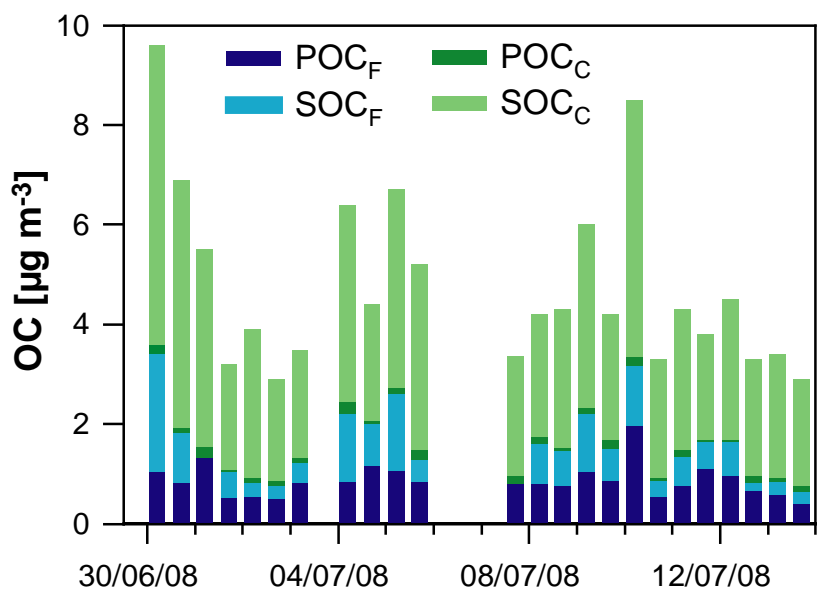

Fig. 2. Time series of ambient organic carbon source estimates. Sources are classified according to the OC origins: primary vs. secondary and fossil vs. contemporary, using CMB modelling and radiocarbon data. In the context of the overall $\mathrm{OC}$ mass balance, $\mathrm{POC}_{\mathrm{F}}, \mathrm{SOC}_{\mathrm{F}}, \mathrm{POC}_{\mathrm{C}}$ and $\mathrm{SOC}_{\mathrm{C}}$ contribute on average for $19.4 \%$, $17.6 \%, 2.5 \%$ and $60.5 \%$, respectively.

SOC. For convenience reasons and because it is not possible to assess quantitatively the biases induced by implicit uncertainties underlying $\mathrm{CMB}$ analyses, the $\mathrm{CMB}$ un-apportioned OC will be considered in the following sections as a surrogate of SOC and will be referred to as CMB-SOC fraction.

Another approach for addressing source attribution is through measurements of the radiocarbon content of carbonaceous aerosol $\left({ }^{14} \mathrm{C}\right)$ that enable a direct and quantitative distinction between fossil and non-fossil (contemporary) sources (Bench, 2004; Tanner et al., 2004). Combining radiocarbon data and $\mathrm{CMB}$ results enables to gain additional insights into the origins of the particulate carbon, including primarily its secondary fraction. The radiocarbon measurement apportions the fossil $\left(\mathrm{TC}_{\mathrm{F}}\right)$ and contemporary $\left(\mathrm{TC}_{\mathrm{C}}\right)$ fractions of carbon $(\mathrm{EC}+\mathrm{OC})$ that can be oxidized at $850{ }^{\circ} \mathrm{C}$ under oxygen. With this in mind, primary carbon (OC and EC) apportioned by the CMB is classified into two categories, as having contemporary or fossil origins. The primary contemporary carbon $\left(\mathrm{PC}_{\mathrm{C}}\right)$ originates from biomass burning and vegetative detritus whereas the primary fossil carbon $\left(\mathrm{PC}_{\mathrm{F}}\right)$ originates from vehicular emissions, industrial emissions, and natural gas combustion.

EC, contributing on average to $22 \%$ of the total carbon, can be explained almost entirely by primary fossil sources, mainly vehicular emissions. This is in agreement with results from previous source apportionment studies conducted in European remote sites and in urban areas in the US, which suggest a summertime share of fossil-derived EC well above 90\% (Gelencser et al., 2007; Ke et al., 2007). OC can also be divided into the following basic classes: fossil CMB-primary OC $\left(\mathrm{POC}_{\mathrm{F}}\right)$, contemporary CMB-primary $\mathrm{OC}\left(\mathrm{POC}_{\mathrm{C}}\right)$, and the $\mathrm{CMB}$ un-apportioned $\mathrm{OC}$ considered as a surrogate of
SOC. The latter fraction is subdivided into two subcategories: contemporary secondary $\mathrm{OC}\left(\mathrm{SOC}_{\mathrm{C}}\right)$ and fossil secondary $\mathrm{OC}\left(\mathrm{SOC}_{\mathrm{F}}\right)$, following Eqs. (1) and (2):

$$
\begin{aligned}
& \mathrm{SOC}_{\mathrm{C}}=\mathrm{TC}_{\mathrm{C}}-\mathrm{PC}_{\mathrm{C}} \\
& \mathrm{SOC}_{\mathrm{F}}=\mathrm{TC}_{\mathrm{F}}-\mathrm{PC}_{\mathrm{F}}
\end{aligned}
$$

It is worthwhile to note that these two fractions are conceptually equivalent to the CMB-SOC fraction. Subsequently, they are subjected to the same type of uncertainties resulting from the CMB analysis. On the one hand, since the major primary sources considered by the CMB model are essentially of fossil origin (vehicular emissions and industrial emissions) during the period of our study, uncertainties associated with the CMB model (i.e. profile selection and photochemical decay of primary markers) will majorly affect the $\mathrm{SOC}_{\mathrm{F}}$ fraction. On the other hand, the $\mathrm{SOC}_{\mathrm{C}}$ fraction could comprise small contributions from unconsidered primary biogenic $\mathrm{OC}$, including contributions from primary marine OA (PMOA) whose estimation remains among the least constrained. Based on the $\mathrm{Na}^{+}$concentrations and the $\mathrm{Na}^{+}$-to-OC ratios provided by Russell et al. (2010) for emissions from ocean bubble bursting, the contribution of PMOA can be roughly estimated at less $0.1 \mu \mathrm{g} \mathrm{m}^{-3}$ or $2.3 \%$ of the total OC mass (or $3.8 \%$ of the $\mathrm{SOC}_{\mathrm{C}}$ fraction - see discussion below). Overall, $\mathrm{SOC}_{\mathrm{C}}$ and $\mathrm{SOC}_{\mathrm{F}}$ fractions can be regarded, consequently, as upper limits for the mass concentrations of the SOC from contemporary and fossil origin, respectively.

Figure 2 presents the temporal series of OC mass balance resulting from the integrated source apportionment approach described above. From there, it is possible to evaluate the relative importance of primary versus secondary and anthropogenic versus biogenic sources to the total OC mass. The total fossil OC contributes on average to $37 \%$ of OC mass $\left(1.7 \mu \mathrm{g} \mathrm{m}^{-3}\right)$, of which $53 \%\left(0.9 \mu \mathrm{g} \mathrm{m}^{-3}\right)$ is of primary origin and $47 \%\left(0.8 \mu \mathrm{g} \mathrm{C} \mathrm{m}^{-3}\right)$ is of secondary origin. This last fraction can most probably be attributed to SOA formation from anthropogenic sources. Such apportionment agrees with previous ambient data indicating substantial new OA formation downwind of main anthropogenic sources (Heald et al., 2005; Volkamer et al., 2006). Unlike EC, organic carbon is dominated by contemporary sources that account for $63 \%$ on average of the OC mass $\left(2.7 \mu \mathrm{g} \mathrm{C} \mathrm{m}^{-3}\right)$, consistent with previous ${ }^{14} \mathrm{C}$ summertime measurements conducted in European remote sites and urban areas in the U.S. (Hodzic et al., 2010). Not unexpectedly, the relative share of the summertime contemporary POC is virtually negligible, contributing on average to $3 \%$ of the total OC $\left(0.13 \mu \mathrm{g} \mathrm{C} \mathrm{m}^{-3}\right)$. The most striking feature is that contemporary SOC establishes the major contribution during the entire period of study, ranging between 48 and $71 \%$ of the total OC (average of $60 \%$ or $2.5 \mu \mathrm{g} \mathrm{C} \mathrm{m}^{-3}$ ). As a comparison, this fraction accounts on average for $77 \%$ of the secondary carbon (CMB$\mathrm{SOC})$. Since $\mathrm{SOC}_{\mathrm{c}}$ is mainly formed from processing of biogenic precursors, this represents a very large share for PM 
collected at a site located in a dense urban area. Such a result supports other summertime source apportionment studies that evidenced the high proportion of SOA and pointed towards the predominance of biogenic SOA (Gelencser et al., 2007). In view of these observations, the SOA of biogenic origin in our samples is further explored in the next sections through the markers of some of the key biogenic precursors.

\section{Traditional biogenic SOC}

Contributions of SOC from biogenic precursors (isoprene, $\alpha$ pinene, and $\beta$-caryophyllene; referred to as "traditional biogenic SOC") to the ambient OC mass can be estimated using the marker-based approach developed by Kleindienst et al. (2007). This approach consists of converting the measured concentrations of marker compounds derived from a given precursor hydrocarbon (HC) into a SOC concentration $\left([\mathrm{SOC}]_{\mathrm{HC}}\right)$, using the laboratory-generated mass fractions of the same markers $\left(f_{\mathrm{SOC}, \mathrm{HC}}\right)$ determined by Kleindienst et al. (2007). [SOC $]_{\mathrm{HC}}$ can be subsequently calculated as follows:

$$
[\mathrm{SOC}]_{\mathrm{HC}}=\frac{\sum_{i}^{J}[M]_{i}}{f_{\mathrm{SOC}, \mathrm{HC}}}
$$

where $[M]_{i}$ is the concentration of the marker $i$ and $J$ is the total number of markers derived from the hydrocarbon HC. The set of markers used for the apportionment is reported in Table 1. These include: 2-methylglyceric acid (2-MGA), 2-methylthreitol (2-MT1) and 2-methylerythritol (2-MT2) as isoprene SOC markers; pinonic acid, pinic acid and A1-A7 compounds as $\alpha$-pinene SOC markers; and $\beta$-caryophyllinic acid as $\beta$-caryophyllene SOC marker. The $f_{\mathrm{SOC}, \mathrm{HC}}$ factors are $0.155 \pm 0.039$ for isoprene, $0.231 \pm 0.111$ for $\alpha$-pinene and $0.0230 \pm 0.0046$ for $\beta$-caryophyllene (Kleindienst et al., 2007).

The contributions assessed using this approach (Table 2) must be regarded as estimates since they are based on the use of a single value for $f_{\mathrm{SOC}, \mathrm{HC}}$ that clearly cannot fully capture the complexity of tropospheric radical-driven chemical mechanisms, the wide range of compounds introduced in the troposphere, and the myriad of potential meteorological conditions (RH, $T, J_{\mathrm{NO}_{2}} \ldots$ ). Furthermore, the concept of the source apportionment approach used here is retrospective in the sense that the SOC mass is reconstructed from the concentration of supposedly-conservative specific markers, while any of their further reactions would yield an underestimation of the SOC mass. At present, there is a real paucity of data regarding the chemical stability of the markers used here (Kessler et al., 2010). Nevertheless, because clearly better techniques are currently lacking, we will base our discussion on estimates computed using this approach. In addition, this will allow a direct comparison of our results with published data.

\subsection{Isoprene SOC}

\subsubsection{Average contributions}

The contribution from isoprene SOC is estimated by the mean of three markers: 2-methylglyceric acid (2MGA) and the two diastereoisomers, 2-methylthreitol (2MT1) and 2-methylerythritol (2-MT2), collectively known as 2-methyltetrols (2-MT). 2-methyltetrols are generated in the atmosphere upon isoprene photo-oxidation, while 2-methylglyceric acid is formed by further oxidation of methacrolein, a major gas phase oxidation product of isoprene (Carlton et al., 2009 and references therein). The presence of these markers has been confirmed in a number of studies spanning a wide range of biogenically-influenced environments (Carlton et al., 2009). Atmospheric concentrations of 2-methyltetrols reported in these studies are in the range of $0.02-365 \mathrm{ng} \mathrm{m}^{-3}$, with the highest concentrations measured during summer in Research Triangle Park (NC, USA), a suburban site in the Southeastern USA. In Marseille, 2-methyltetrol concentrations range between 0.02 and $13 \mathrm{ng} \mathrm{m}^{-3}$ with an average of $1.9 \mathrm{ng} \mathrm{m}^{-3}$ (Table 2), falling towards the low end of concentration ranges previously reported (Carlton et al., 2009 and references therein). The excellent correlation $\left(R^{2}=0.98, n=26\right)$ observed between the concentrations of the two diastereoisomers is consistent with their formation through the same process (Fig. 4). The mass concentration ratio 2-MT2-to-2-MT1, inferred from the slope of the linear regression between the two diastereoisomers, is 2.8, in agreement with data from Ion et al. (2005). With regards to 2-methylglyceric acid, its ambient concentrations range in our case between 0.027 and $5.9 \mathrm{ng} \mathrm{m}^{-3}$, falling within the range of concentrations reported for other European sites (Ion et al., 2005; Kourtchev et al., 2009; Kourtchev et al., 2008). Using the sum of marker concentrations and the laboratory-derived $f$ soc value, contribution of isoprene SOC is estimated at $0.024 \mathrm{\mu g} \mathrm{m}^{-3}$. Expressed as percentage contribution to the $\mathrm{PM}_{2.5} \mathrm{OC}$, isoprene $\mathrm{SOC}$ represents, on average, $0.58 \%$ (Table 2), which is one to two order of magnitude lower than contributions found in urban background sites in the Midwestern US (Lewandowski et al., 2008; Stone et al., 2009). In contrast, our results compare well with those reported in a study conducted in the Los Angeles Air Basin (Stone et al., 2009; Table 2).

\subsubsection{Insights into isoprene chemistry}

Figure 3 presents the temporal trends of concentrations for isoprene (12h average) and isoprene SOC markers (i.e. 2methylglyceric acid and 2-methyltetrols). Unlike previous findings reported in biogenic OA studies in forested sites (Ion et al., 2005; Kourtchev et al., 2008), isoprene SOC markers do not display a diurnal variation during the period of study. It seems that the regional transport and the variability of the sources and the air mass origins overwhelm the local 
Table 2. Average concentrations and concentration range (min-max) of particulate biogenic major oxidation products measured in $\mathrm{PM}_{2.5}$ from Marseille during 2008 summer period compared to other studies from contrasted areas. Also reported are the contributions [\%] to OC mass from primary sources, isoprene SOC, $\alpha$-pinene SOC, $\beta$-caryophyllene SOC and the OC fraction that is not attributed to these sources (other-SOC).

\begin{tabular}{|c|c|c|c|c|c|c|}
\hline & $\begin{array}{l}\text { This study } \\
\text { (July) }\end{array}$ & $\begin{array}{l}\text { Urban Midwestern } \\
\text { US } 1 \text { (July) }\end{array}$ & $\begin{array}{l}\text { Urban Midwestern } \\
\text { US } 2 \text { (July) }\end{array}$ & $\begin{array}{l}\text { Urban Los } \\
\text { Angeles US } \\
\text { (July) }\end{array}$ & $\begin{array}{l}\text { Forested site } \\
\text { Germany } \\
(\text { July })^{\mathrm{c}}\end{array}$ & $\begin{array}{l}\text { High arctic } \\
\text { (winter- }^{\text {summer) }}{ }^{\mathrm{d}}\end{array}$ \\
\hline \multicolumn{7}{|c|}{ Main SOC markers $\left[\mathrm{ng} \mathrm{m}^{-3}\right]$} \\
\hline 2-MGA & $1.8(0.03-5.9)$ & 21.5 & nd & nd & 2.4 & 0.194 \\
\hline 2-MT & $1.9(0.02-13)$ & 86 & 35.1 & 6.35 & 16.1 & 0.032 \\
\hline A1 & $3.5(0.26-14)$ & 45.3 & 17 & 19 & 4.8 & 0.471 \\
\hline A7 & $5.1(0.33-18)$ & 24 & 1.9 & 3.4 & 5.2 & 0.647 \\
\hline PNA & $15(1.6-34)$ & 3.6 & 6.7 & 10.4 & nd & 0.069 \\
\hline PA & $4.5(0.82-12)$ & 2.6 & 3.4 & 6.7 & 3.0 & 0.514 \\
\hline $\mathrm{C}$ & $0.27(0.01-1.1)$ & 3.5 & 1.2 & 1.8 & nd & 0.120 \\
\hline \multicolumn{7}{|c|}{ Contribution to OC [\%] } \\
\hline $\begin{array}{l}\text { Total primary } \\
\text { OC }\end{array}$ & $22(13-31)$ & 36 & 40 & 21 & 3.6 & nd \\
\hline Isoprene SOC & $0.58(0.10-2.5)$ & 25 & 7 & 0.7 & 2.5 & 0.78 \\
\hline$\alpha$-pinene SOC & $3.4(0.6-8.5)$ & 19 & 5.9 & 2.8 & 2.4 & 2.54 \\
\hline $\begin{array}{l}\beta \text {-caryophyllene } \\
\text { SOC }\end{array}$ & $0.25(0.05-0.89)$ & 5.5 & 1.7 & 1.2 & nd & 1.73 \\
\hline other-SOC ${ }^{\dagger}$ & $74(65-85)$ & 14 & 45 & 74 & 91.5 & 95 \\
\hline
\end{tabular}

nd: not determined

Isoprene oxidation products: 2-MGA=2-methylglyceric acid and 2-MT=2-Methylthreitol + 2-Methylerythritol.

$\alpha$-Pinene oxidation products: A1=3-hydroxyglutaric acid, A7=3-methyl-1,2,3-butanetricarboxylic acid, PNA=pinonic acid and PA=pinic acid. 3-methyl-1,2,3-butanetricarboxylic acid (A7) may be under another notation in the cited studies owing to the revision of its chemical structure (Szmigielski et al. 2007).

$\beta$-Caryophyllene oxidation products: $\mathrm{C}=\beta$-caryophyllenic acid.

$\dagger$ Other-SOC is the OC fraction that is not attributed to primary sources or to traditional secondary sources (Sect. 5).

${ }^{a}$ Lewandowski et al. (2008): Primary sources were assessed using CMB modelling

b Stone et al. (2009): Primary sources were assessed using CMB modelling

c Kourtchev et al. (2008): Primary sources denote only biomass burning apportioned using levoglucosan concentrations

${ }^{\mathrm{d}} \mathrm{Fu}$ et al. (2009).

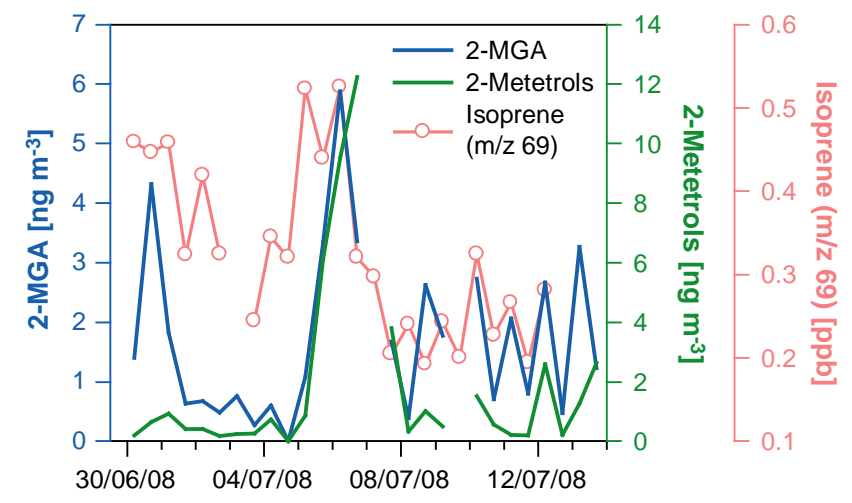

Fig. 3. Temporal trends of isoprene $[\mathrm{ppb}]$ and isoprene particulate phase oxidation products $\left[\mathrm{ng} \mathrm{m}^{-3}\right]$ : 2-methylglyceric acid (2-MGA) and 2-methyltetrols (the sum of 2-methylthreitol and 2methylerythritol). photochemistry. This regional impact is especially clear in the case of industrial emissions (see companion paper), but can also be noticed from the isoprene gas-phase concentrations (Fig. 3) as a substantial enhancement in isoprene concentrations and its oxidation products seems to be observed when the site was subjected to clean air masses from the Mediterranean. These periods are most likely related to air masses highly impacted by biogenic emissions. Indeed, a larger dataset would be most useful to confirm these trends.

More importantly, Figs. 3 and 4 reveal that 2methylglyceric (2-MGA) acid and 2-methyltetrols (2-MT) display different temporal trends. Although both 2-MT and 2-MGA originate from the photo-oxidation of isoprene, $\mathrm{NO}_{\mathrm{x}}$ concentrations and aerosol acidity (Surratt et al., 2007; Surratt et al., 2006) may affect their formation processes and, as a result, their relative abundances. Moreover, relative abundances of these organic compounds can evolve as they can undergo further photochemical processing or heterogeneous reactions upon their formation (Robinson et al., 2007). 

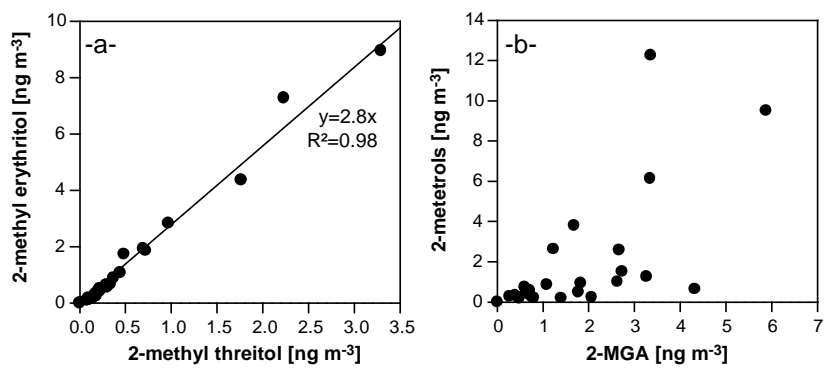

Fig. 4. Scatter plots between isoprene particulate phase oxidation products: (a)2-Methylerythritol vs. 2-Methylthreitol. (b) 2methyltetrols vs. 2-methylglyceric acid (2-MGA). Excellent correlation found between the two diastereoisomers (2-methylthreitol and 2-methylerythritol) is consistent with their formation through the same photo-oxidation process. The mass concentration ratio 2methylerythritol-to-2-methylthreitol determined from the linear relationship is 2.8. In contrast, the 2-methyltetrols does not show a clear correlation with 2-methylglyceric acid suggesting that their formation through the photo-oxidation of isoprene is influenced by ambient conditions.

\section{Impact of $\mathrm{NO}_{\mathrm{x}}$ concentrations}

In order to gain additional insights into isoprene SOC marker formation, $12 \mathrm{~h}$-average concentrations of isoprene are plotted versus its major gas-phase oxidation products, methylvinylketone (MVK) and methacrolein (MACR) (Fig. 5a). Under some idealized assumptions, concentration ratios of precursor hydrocarbons and their photochemical oxidation products can be used as a surrogate of the air mass photochemical age. An average ratio of (MVK+MACR)-toisoprene of 0.4 (0.2-0.7; Fig. S2, second pannel) is observed, implying a large contribution of oxygenated compounds in air masses sampled during the field campaign (Montzka et al., 1993). The relatively weak correlation $\left(R^{2}=0.6 n=22\right.$; Fig. 5a) between isoprene and its oxidation products implies some remaining variability in the relationship between the two variables. As evoked beforehand, this variability can be assigned, in part, to a variation of the photochemical activity of the atmosphere, as more processed air masses would be characterized by higher (MVK+MACR)-to-isoprene ratios.

However, another factor altering (MVK+MACR)-toisoprene ratios is the influence of $\mathrm{NO}_{\mathrm{x}}$ concentrations on isoprene chemistry. As demonstrated by Surratt et al. (2006) the distribution of isoprene photo-oxidation products depends heavily on the fate of isoprene peroxy radicals $\left(\mathrm{iRO}_{2}\right)$ : In polluted atmospheres (high- $\mathrm{NO}_{\mathrm{x}}$ regime), $\mathrm{iRO}_{2}$ undergo preferentially reaction with nitric oxide (NO) producing carbonyls (MVK+MACR) and hydroxynitrates. In contrast, in pristine conditions (low- $\mathrm{NO}_{\mathrm{x}}$ regime) reaction of $\mathrm{iRO}_{2}$ with hydroperoxy radicals $\left(\mathrm{HO}_{2}\right)$ tend to prevail, giving rise to hydroxyhydroperoxides (iROOH) with a concomitant formation of (MVK+MACR) in much smaller yields (Carlton et al., 2009; Paulot et al., 2009). Consequently, in low- $\mathrm{NO}_{\mathrm{x}}$ regime, the production of high amounts of $\mathrm{iROOH}$ with respect to (MVK+MACR) is expected to translate into lower (MVK+MACR)-to-isoprene ratios. As shown in Fig. 5a, such behavior is observed, highlighted by the data points that spread beneath the $0.4: 1$ line.

It seems that the branching described above has a significant impact on the formation of isoprene SOC markers (2MT and 2-MGA). Low (MVK+MACR)-to-isoprene ratios are associated with high 2-MT-to-2-MGA ratios and high isoprene SOC contributions, implying that $\mathrm{NO}_{x}$ plays a major role in the formation of isoprene SOC markers. This is highlighted quite readily in Fig. 5b, as a noteworthy decrease in the 2-MT-to-2-MGA ratios is observed during high levels of $\mathrm{NO}_{\mathrm{x}}$. Further, it can be noticed that there is a trend towards higher isoprene SOC concentrations under low- $\mathrm{NO}_{\mathrm{x}}$ conditions.

These results are consistent with the established formation pathways of isoprene SOC markers, since 2-MGA is a major product under high- $\mathrm{NO}_{\mathrm{x}}$ conditions arising from further reaction of methacrolein (low 2-MT-to-2-MGA), whereas 2MT are mainly detected under low- $\mathrm{NO}_{\mathrm{x}}$ conditions (high 2-MT-to-2-MGA) where higher SOA yields are observed (Kroll et al., 2005, 2006; Surratt et al., 2006). With respect to 2-MT, their formation proceeds through the reaction of $\mathrm{iROOH}$ with $\mathrm{OH}$ radicals that produces isoprene dihydroxyepoxides (iEPOX), followed by the hydrolysis of the latter upon its uptake onto aerosol surfaces (Paulot et al., 2009). This is consistent with their high relative abundance during low (MVK+MACR)-to-isoprene ratios. These results underline the complex nature of radical-driven mechanisms leading to isoprene SOC formation and their sensitivity to ambient concentrations of $\mathrm{NO}_{\mathrm{x}}$.

\section{Aerosol acidity and marker decay}

Another critical parameter deeply affecting isoprene SOC formation is aerosol acidity, as recent laboratory studies suggest an enhancement of SOA mass under acidic conditions (Surratt et al., 2007). Such a trend is not straightforward in our results, showing some extent of decrease of isoprene SOC contributions with aerosol acidity, the latter being assessed by the deficit of ammonium over nitrate and sulfate ions (see Fig. 6). A possible explanation for this discrepancy is that acidic aerosol is associated, in Marseille, with anthropogenic air masses characterized by high concentrations of NO, which would severely depress the formation of isoprene SOC.

At this point of discussion, decay of isoprene markers enhanced by aerosol acidity cannot be ruled out as another possible explanation, all the more since low isoprene SOC contributions seem to be associated with processed air masses (high MACR+MVK-to-isoprene ratios, Fig. 5a). It has been suggested that acidic surface of ambient aerosol gives rise to organosulfate compounds $\left(\mathrm{RSO}_{4} \mathrm{H}\right)$ or oligomers that would 

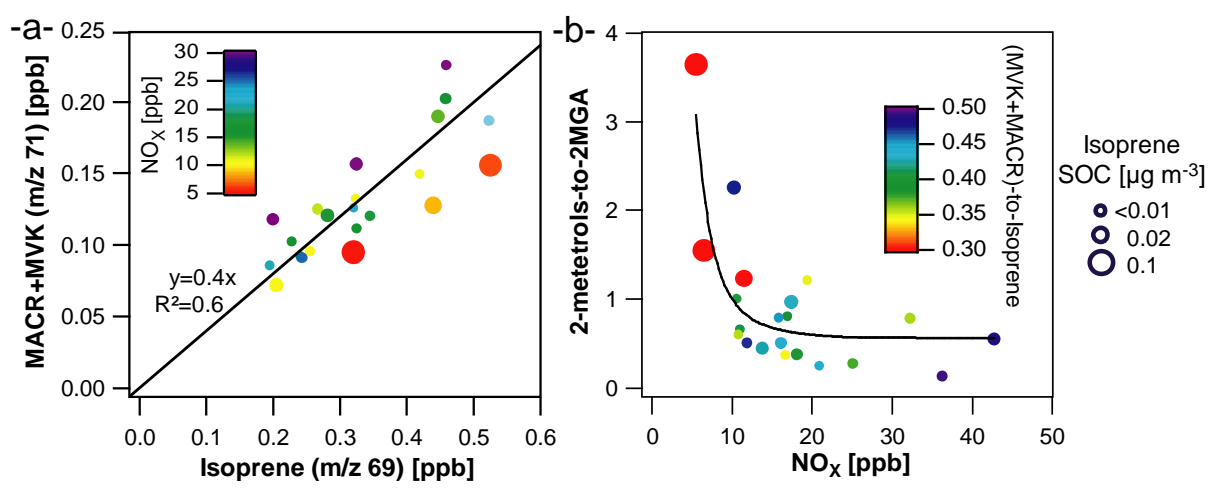

Fig. 5. Insights into the formation pathways of isoprene SOA: (a)Isoprene major gas phase oxidation products (Sum of methacrolein (MACR) and methyl vinyl ketone (MVK)) vs. isoprene. (b) 2-methyltetrols-to-2-MGA ratios vs. $\mathrm{NO}_{\mathrm{x}}$ concentrations. Point colours are mapped by $\mathrm{NO}_{\mathrm{x}}$ concentrations in (a) and by (MACR+MVK)-to-isoprene ratios in (b). Red colour indicates lower $\mathrm{NO}_{\mathrm{x}}$ concentrations and (MACR+MVK)-to-isoprene ratios that are associated with higher isoprene SOC mass loadings. Sizes of points are weighted by the isoprene SOC mass estimated using conversion factor reported by Kleindienst et al. (2007).

originate from the further reactivity of particulate phase organic compounds including, specifically, 2-methyltetrols (Surratt et al., 2008). The formation of such compounds upon the transformation of isoprene markers would explain the decrease of isoprene SOC contributions with the increase of aerosol acidity observed in Fig. 6 and lead to an underestimation of isoprene SOC contributions estimated using this approach. Although, there is a paucity of data regarding the stability of isoprene SOC markers several laboratory studies and field measurements point towards a further reactivity of these compounds (Carlton et al., 2009). In this regard, recent laboratory investigations of the photochemistry of isoprene have brought strong evidence for continuing chemistry even after aerosol formation (Surratt et al., 2006) and the fast heterogeneous oxidation of erythritol (a surrogate of 2-MT) was recently demonstrated (Kessler et al., 2010). In ambient atmospheres, seasonal trends in biogenic SOA markers over the southeastern United States (Ding et al., 2008) suggest that formation of 2-methyltetrols is mainly influenced by local emissions rather than large scale atmospheric transport, a fact that can possibly be assigned to the reactivity of these markers during atmospheric transport. In photochemically very active environments (high ozone, often acidic seed) such as Marseille's, the marker stability might be even lower. In the eastern Mediterranean, it was shown that in cases of around 1-day aging of an urban plume, there was basically no sign of any primary contributions, indicating a fast transformation of primary organics (Hildebrandt et al., 2010). This might indicate that any molecular marker, including isoprene photooxidation products, potentially undergo further reactions efficiently, at least in this region. Indeed, it would be worthwhile to confirm in further long-term measurements the occurrence of compounds originating from the aging of marker compounds used here. In parallel, further laboratory work is required to provide additional insights into the stability of SOC organic markers.

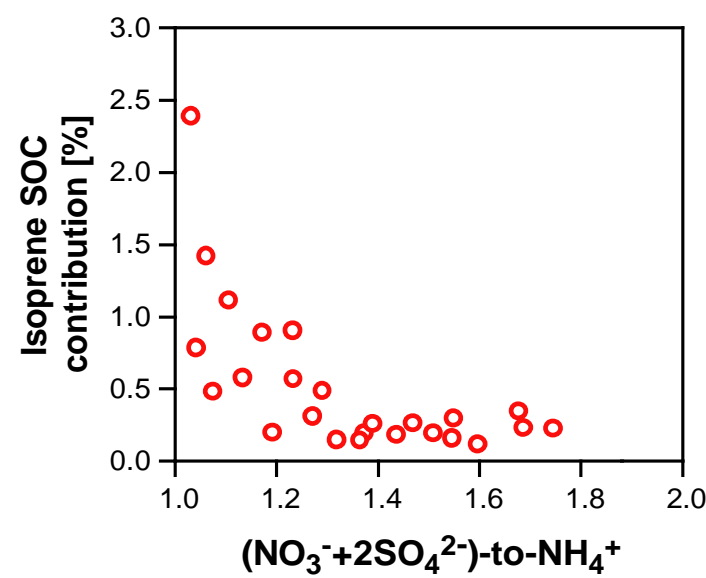

Fig. 6. Scatter plot of isoprene SOC contributions vs. aerosol acidity assessed by the deficit of ammonium against sulphates and nitrates.

\subsubsection{Sensitivity of isoprene SOC estimates}

The discussion above naturally prompts the question about the consequences of such changes in the isoprene chemistry on the assessment of isoprene SOC. In order to try to address this question, the approach discussed above (referred to as $f_{\text {SOC }}$ approach) is slightly revised. Calculations based on $f_{\text {SOC }}$ approach (Eq. 3) imply two implicit sources of uncertainties. First, the estimation of source contributions relies heavily on a single marker-to-SOC ratio determined in the presence of $\mathrm{NO}_{\mathrm{x}}$ (Kleindienst et al., 2007) and assumed to be stable and representative of an average isoprene SOC. This assumption is challenged by potentially multigenerational chemistry occurring in the atmosphere and the highly variable nature of radical-driven chemical mechanisms. Second, simply considering the sum of markers as a 
macro-tracer to infer SOC mass may overlook the variability within the profile of molecular markers highlighted notably above by the variation in 2-MT-to-2-MGA ratios. To assess these uncertainties, the approach adopted here considers more than a single solution (or estimation), by using different marker-to-SOC ratios as conversion factors. These factors consist of 2-MGA-to-SOC, 2-MT-to-SOC and (2$\mathrm{MGA}+2-\mathrm{MT})$-to-SOC, determined in distinct experimental conditions: isoprene/ $\mathrm{NO}_{\mathrm{x}} / \mathrm{SO}_{2}\left(f_{\mathrm{SOC}}\right.$ factor, (Kleindienst et al., 2007)), isoprene in absence of $\mathrm{NO}_{\mathrm{x}}$ (Kleindienst et al., 2009) and isoprene/ $\mathrm{NO}_{\mathrm{x}}$ in presence of inorganic aerosol seeds $\left(\left(\mathrm{NH}_{4}\right)_{2} \mathrm{SO}_{4} / \mathrm{H}_{2} \mathrm{SO}_{4}\right)$ of varying acidity: stage 1 is related to neutral seeds and stage 4 to acidic seeds (Surratt et al., 2007). Comparison between estimates derived from different marker-to-SOC drawn from different chamber experiments provides insights into the sensitivity of the apportionment results to the selection of the source profiles and markers.

Figure 7 displays estimates of isoprene SOC computed using the approach described above. Comparing these estimates reveal a striking variability, as an average factor of 60 (10-200) is observed between the upper and lower ends of the estimate range. This wide range encompasses 3 different sources of biases:

1. A part of the biases in the estimates can be assigned to the use of two different surrogates for the quantification of 2-MT and for 2-MGA (Table 1) rather than a single compound as it was used in chamber experiments (Kleindienst et al., 2007; Kleindienst et al., 2009; Surratt et al., 2007). Taking into account the difference between response factors of 2-MT and 2-MGA surrogates (Table 1), this bias could at most be reduced by a factor of 1.7, if a single compound was used for these quantifications.

2. Another critical parameter underlying a part of these biases is the use of marker-to-SOC ratios drawn from chamber experiments conducted for different conditions. These biases are systematic and can be inferred by simply comparing source profiles as more OC will be apportioned using profiles with smaller marker-to-SOC ratio. For a given marker (represented in Fig. $7 \mathrm{~b}$ by the same symbol), differences within this ratio across published profiles does not exceed a factor of three creating similar variability in the estimates (Kleindienst et al., 2007; Kleindienst et al., 2009; Surratt et al., 2007).

3. The variability in the estimates is essentially related to the choice of isoprene SOC marker used for the estimation, which is interpreted as the significant differences between chemical profiles obtained in ambient and chamber conditions (Fig. S3) and the lower 2-MTto-2-MGA in our case. In the supporting information, the profiles of ambient isoprene SOA markers found in this study are compared in terms of 2-MT-to-2-MGA
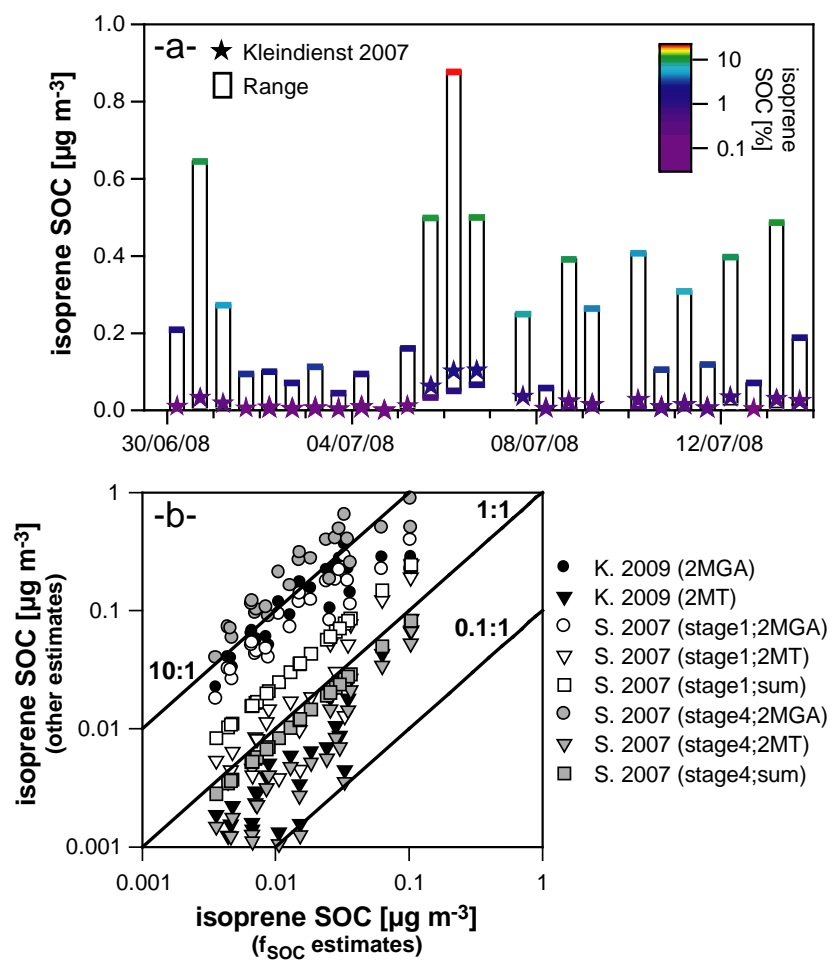

Fig. 7. Isoprene SOC estimates determined using the mass fraction of isoprene markers (marker-to-SOC) as conversion factor. The sensitivity of the estimates was evaluated by considering different markers-to-SOC ratios: 2MGA-to-SOC, 2MT-to-SOC and Sum(2MGA and 2MT)-to-SOC determined in different chamber experimental conditions. Photo-oxidation experiment conditions include: isoprene/ $\mathrm{NO}_{\mathrm{x}} / \mathrm{SO}_{2}$ (Kleindienst et al. 2007), isoprene in absence of $\mathrm{NO}_{\mathrm{x}}$ (Kleindienst et al. 2009, here abbreviated with $\mathrm{K} .2009)$ and isoprene/ $\mathrm{NO}_{\mathrm{X}}$ in presence of inorganic aerosol seeds $\left(\left(\mathrm{NH}_{4}\right)_{2} \mathrm{SO}_{4} / \mathrm{H}_{2} \mathrm{SO}_{4}\right)$ of varying acidity: stage1 denotes neutral seeds and stage 4 denotes acidic seeds (Surratt et al., 2007; here abbreviated with S. 2007). Panel (a) presents the time series of isoprene SOC contribution: Boxes show the range of contribution estimates for all of the different conversion factors ( 9 factors) and stars represents contributions estimated using Sum (2MGA and 2MT)-toSOC reported in Kleindienst et al., 2007. The latter conversion factor, referred to as $f_{\mathrm{SOC}}$, is used as a reference factor applied in several studies to apportion isoprene SOA. Point colours are mapped by the contribution of isoprene SOC to total OC that ranges between $0.03 \%$ and $20 \%$, depending on the selected marker-to-SOC factor. Panel (b) presents the correlation of isoprene SOC estimated using different conversion factors vs. $f_{\text {SOC }}$ contribution results. Black lines indicate 10:1, 1:1 and 0.1:1 ratios between the different estimates and $f_{\text {SOC }}$ estimates.

with those reported in other ambient atmospheres and in chamber experiments (Fig. S3). The comparison between ambient data with chamber experiments reveals a noteworthy deficit in 2-MT ambient levels compared to those of 2-MGA, in urban environments. For instance, ambient 2-MT-to-2-MGA ratios range between 0.3 and 
3.7 in this study, whereas the same ratio reported in chamber experiments ranges between 12 and 30 (Kleindienst et al., 2007; Kleindienst et al., 2009; Surratt et al., 2007). Accordingly, greater biases can be noticed between solutions derived from high 2-MT-to-SOC ratios (triangles down; Fig. 7b) and those derived from low 2-MGA-to-SOC ratios (circles; Fig. 7b). In particular, the lowest amount of ambient OC apportioned to isoprene SOC is estimated at $0.01 \mu \mathrm{g} \mathrm{C} \mathrm{m}{ }^{-3}$ or $0.24 \%$ [0.005-1.5\%] of OC, using 2-MT-to-SOC as a conversion factor drawn from Surratt et al (2007)-stage 4 experiment. In contrast, at the upper limit, isoprene SOC is estimated to contribute $0.25 \mu \mathrm{g} \mathrm{C} \mathrm{m}^{-3}$ or $5.7 \%$ [0.68$20 \%$ ] of the ambient OC, using 2-MGA-to-SOC as a conversion factor drawn from Surratt et al. (2007)-stage 4 experiment. As mentioned earlier, these noteworthy differences observed between ambient data and chamber experiments can presumably be assigned to different formation pathways of markers (i.e. $\mathrm{NO}_{\mathrm{x}}$ chemistry) or to decay of markers (i.e. Lower ambient 2-MT-to-2MGA ratios might indicate that 2-MT are more reactive than 2-MGA and they are consumed preferentially by photochemistry or by heterogeneous reactions). Finally, it is worth mentioning that since isoprene markers does not show constant ambient profiles (Figs. 4 and 5), these biases are not systematic and greater differences arise when 2-MT is severely depleted against 2-MGA (Fig. 5b).

These sensitivity tests highlight the uncertainties underlying SOC assessment using a marker-based approach. The main conclusions from this analysis is that even if there are little differences in available source profiles conducted in different experimental conditions, the main biases and variability arise from the choice of isoprene SOC markers. It follows that the available profiles do not reflect the actual isoprene SOC composition observed in Marseille, pointing out the need for more source characterization and a better understanding of the stability of molecular markers. In addition, given the variability in ambient profiles of marker compounds, assessment of isoprene SOC must be addressed using more than an individual source profile, allowing a better capture of varying conditions influencing SOC formation. These concerns hinder accurate estimation of isoprene SOC contribution in our case and may explain a significant part of the variability in the reported isoprene SOA concentrations in different locations, ranging from practically negligible to potentially dramatic (Table 2).

\section{$4.2 \alpha$-pinene and $\beta$-caryophyllene SOC}

Markers derived from photo-oxidation of $\alpha$-pinene include pinic (PA) and pinonic (PNA) acid, as well as a set of seven higher-generation oxidation products (A1-A7). Figure 8 represents the time series of $\alpha$-pinene SOC markers.

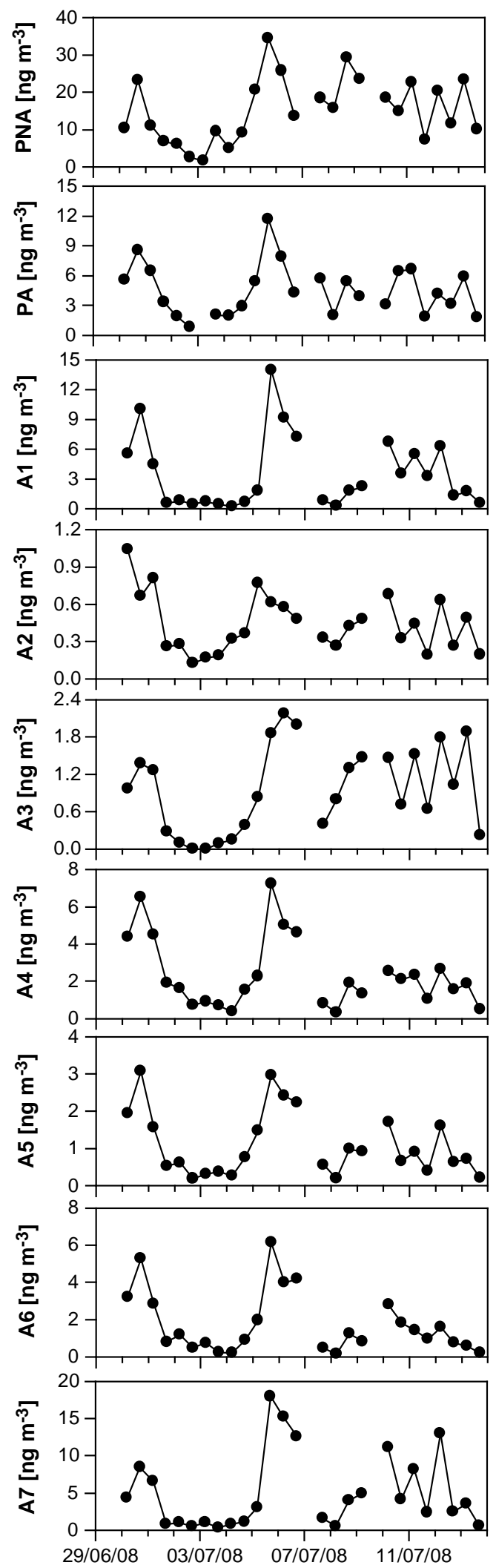

Fig. 8. Time series of $\alpha$-pinene oxidation products. 
Unlike isoprene SOC markers, the concentrations of these markers display common temporal patterns. In particular, higher-generation products such as A1 and A4-A7 are highly correlated $\left(R^{2}=0.71-0.94, \mathrm{n}=26\right)$, consistent with a similar formation process at a similar time scale. Conversely, these products present lower correlations $\left(R^{2}=0.41-0.64\right)$ with lower-generation oxidation products (i.e. PNA and PA), which is most probably related to the variability in the extent of $\alpha$-pinene photo-oxidation.

Pinic acid is detected with average concentrations of $4.5 \mathrm{ng} \mathrm{m}^{-3}$ (range $0.8-12.0$ ), fairly comparable with concentrations measured in preceding studies conducted in urban areas and forested sites (Table 2). Pinonic acid concentrations range between 1.6 and $34 \mathrm{ng} \mathrm{m}^{-3}$, with an average concentration of $15 \mathrm{ng} \mathrm{m}^{-3}$, which is slightly higher than concentrations previously reported (Table 2). Among the higher generation oxidation products, it is believed that both 3-hydroxyglutaric acid (A1) and 3-methyl-1,2,3butanetricarboxylic acid (A7) arise from further oxidation of pinonic acid in the presence of $\mathrm{OH}$ radicals and $\mathrm{NO}_{\mathrm{x}}$ (Kourtchev et al., 2009; Szmigielski et al., 2007). Average concentrations of $\mathrm{A} 1$ and $\mathrm{A} 7$ are 3.5 and $5.1 \mathrm{ng} \mathrm{m}^{-3}$ in our study, respectively (Table 2), which is lower than concentrations typically detected in $\mathrm{PM}_{2.5}$ samples collected in urban areas (Kleindienst et al., 2007; Lewandowski et al., 2008). Throughout the campaign, $\alpha$-pinene SOC provides a significant contribution to total SOC, ranging between 0.03 and $0.47 \mu \mathrm{g} \mathrm{m}^{-3}$ (Table 2). This represents between 0.6 and $8.5 \%$ (average $3.4 \%$ ) of total OC, which falls within the range of contributions reported in previous studies conducted in European forested sites (Kourtchev et al., 2009; Kourtchev et al., 2008). The $\beta$-caryophyllene SOC is assessed using $\beta$ caryophyllinic acid as molecular marker; it is estimated to contribute $0.012 \mu \mathrm{g} \mathrm{m}^{-3}$ or $0.25 \%$ [0.05-0.89\%] of the ambient $\mathrm{OC}$, a much smaller contribution that those of isoprene and $\alpha$-pinene. Overall, the estimations of contribution of $\alpha$ pinene SOC and $\beta$-caryophyllene SOC are obviously subjected to the same uncertainties as those developed for isoprene SOC, and have therefore to be considered with the same caution.

\section{Unconsidered secondary sources and processes}

In section 4, we have assessed the contributions from traditional biogenic SOC derived from three key precursor VOC (isoprene, $\alpha$-pinene, $\beta$-caryophyllene) using a marker-based approach. We have demonstrated, furthermore, that these estimates suffer from significant uncertainties associated with our partial understanding of SOC formation and transformation. Based on this approach, the aggregate contribution from traditional BSOC falls in the range between 0.8 and $11 \%$ (average of $4.2 \%$ ). As a result, after considering the combined contribution from primary sources and traditional biogenic secondary sources, $74 \%$ of the total OC, of which
$72 \%$ are from contemporary origins, remains unaccounted for (Table 2). The high amounts of this "residual" SOC, subsequently referred to as "other-SOC", are in agreement with results reported in other source apportionment studies conducted in urban (Los Angeles; Stone et al., 2009) or forested areas (Kourtchev et al., 2009; Kourtchev et al., 2008) (Table 2). Regardless of the uncertainties associated with the approaches used for the source apportionment, the observations above clearly suggest contributions of unconsidered sources or processes to the high amounts of SOC that remains unapportioned. This is further supported by the concentrations of traditional biogenic SOC and CMB-SOC following different temporal trends (Fig. 9).

First, we can consider SOC derived from other biogenic precursor hydrocarbons. It has been clearly shown that VOC emissions from Mediterranean (Parra et al., 2004; Simon et al., 2006) or European (Steinbrecher et al., 2009) vegetation are dominated by monoterpenes accounting on average between 40 and $60 \%$ of the total emitted VOC. The remaining fraction is dominated by isoprene and oxygenated VOC. Among monoterpenes, $\alpha$-pinene accounts in general for less than $20 \%$ of the total monoterpene, suggesting significant contributions from other compounds, mainly myrcene, dlimonene, ocimene and sabinene (Lang-Yona et al., 2010; Owen et al., 2002). In this respect, we have investigated specific SOC marker derived from d-limonene (Jaoui et al., 2006), 3-carboxyheptanedioic acid (L) whose structure was proposed for the first time by Jaoui et al. (2006). Information regarding the analytical determination of this compound is provided in the supporting information (Fig. S3). This compound is clearly present in the $\mathrm{PM}_{2.5} \mathrm{OC}$ and its average concentration is estimated at $0.83 \mathrm{ng} \mathrm{m}^{-3}$ (using malic acid as standard surrogate), which is in the same order of magnitude as concentrations reported in European forested environments (Kourtchev et al., 2009). Using laboratorygenerated mass fraction of this marker determined by Jaoui et al. (2006) (L-to-SOA $=0.0024)$ and assuming SOA-toSOC ratio of $\sim 1.4$ similar to that reported for $\alpha$-pinene SOC (Kleindienst et al., 2007), the SOC derived from d-limonene can be roughly estimated to contribute $0.25 \mu \mathrm{g} \mathrm{m}^{-3}$ or $1.9 \%$ of ambient OC. This contribution is quite low but suggests that the aggregate contribution from SOC derived from the myriad of precursors present in the troposphere could potentially account for a significant fraction of the ambient OC.

A strong piece of evidence supporting this assumption is the presence of an additional set of multifunctional compounds that, to the best of our knowledge, have never been reported in previous hydrocarbon irradiation experiments (Fig. 10). The four unidentified compounds (U1-U4) display a $\left[\mathrm{M}-\mathrm{CH}_{3}\right]^{+}$fragment at $m / z 391$, which relates them to trimethylsilyl derivatives of $\mathrm{C}_{7}$-tricarboxylic acids or $\mathrm{C}_{8^{-}}$ hydroxydicarboxylic acids. It is impossible to provide the precise chemical structures of these compounds on the basis of EI-MS data alone. However, these four isomers exhibit an EI-MS fragmentation pattern similar to that of the 

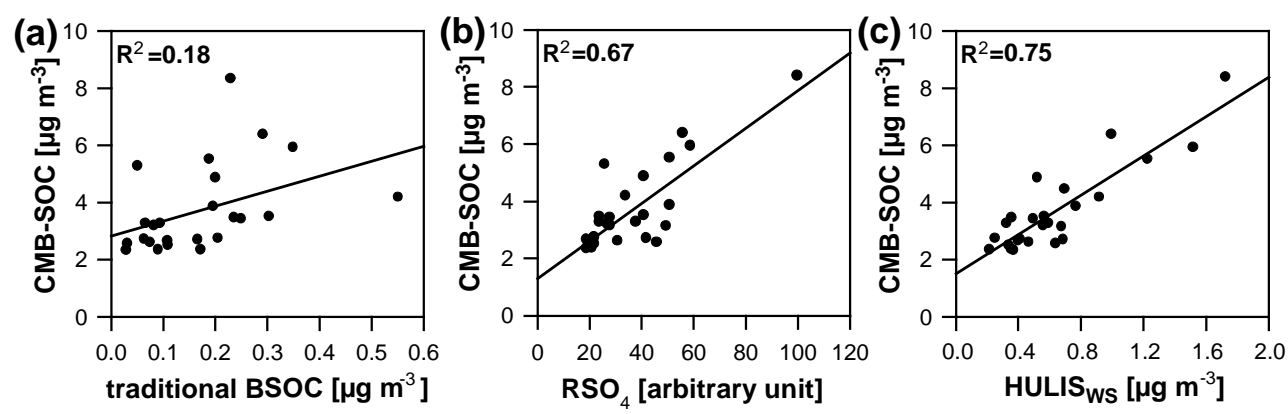

Fig. 9. Scatter plot of CMB-SOC vs. (a) traditional biogenic SOC (SUM of isoprene SOC, $\alpha$-pinene SOC and $\beta$-caryophyllene SOC), (b) organosulfates $\left(\mathrm{RSO}_{4} \mathrm{H}\right)$ and $(\mathbf{c})$ water-soluble HUmic LIke Substances (HULIS $\mathrm{WS}_{\mathrm{S}}$ ).

multifunctional compounds reported in Table 1 and they elute between 22 and $25 \mathrm{~min}$, within the range of retention times of terpene SOC multifunctional markers. Although we cannot associate at present these unidentified markers to specific sources, their presence in the aerosol imply the contribution from other precursors and formation pathways.

Second, we can consider further processing of the organic matter occurring throughout gas-phase photo-oxidation reactions, together with particle-phase polymerization. As discussed in the case of isoprene oxidation products, multigenerational chemistry can significantly alter the freshlyemitted biogenic SOA, which could explain the high proportions of contemporary SOC observed in the present study. An example supporting this assumption is aging of $\alpha$-pinene SOA occurring in chamber experiments through multigenerational photo-oxidation (Szmigielski et al., 2007) or polymerization reactions that forms high molecular weight compounds (Camredon et al., 2010). Accordingly, the contribution of aging processes to other-SOC fraction can be addressed through the study of products potentially originating from these processes, i.e. HULIS and organosulfates $\left(\mathrm{RSO}_{4} \mathrm{H}\right)$ (Fig. 9).

The formation of $\mathrm{RSO}_{4} \mathrm{H}$ could represent up to $20 \%$ of OC in forested sites (Kourtchev et al., 2009). This process takes place on the surfaces of acidic aerosol comprising high amount of inorganic sulphates, as it is the case of the aerosol in Marseille. In our case, $\mathrm{RSO}_{4} \mathrm{H}$ signal was recorded using an APCI-MS/MS approach following the method reported by Dron and co-workers (Dron et al., 2008b; Dron et al., 2007; Dron et al., 2008a). $\mathrm{RSO}_{4} \mathrm{H}$ were analysed under negative mode by MS/MS scans of precursor ions to bisulfate fragment $\left(m / z, 97: \mathrm{HSO}_{4}^{-}\right)$. Figure 9 indicates that $\mathrm{RSO}_{4} \mathrm{H}$ present some extent of correlation with the CMB-SOC fraction $\left(R^{2}=0.67, n=24\right)$, implying that the formation of such compounds could contribute significantly to this fraction. At present, we are unable to provide quantitative assessment for $\mathrm{RSO}_{4} \mathrm{H}$ and it would be worthwhile to quantify such compounds in further work to confirm this assumption.

Additionally, concentrations of HULIS $\mathrm{WS}_{\mathrm{WS}}$ are even more tightly correlated with the CMB-SOC fraction $\left(R^{2}=0.75\right.$
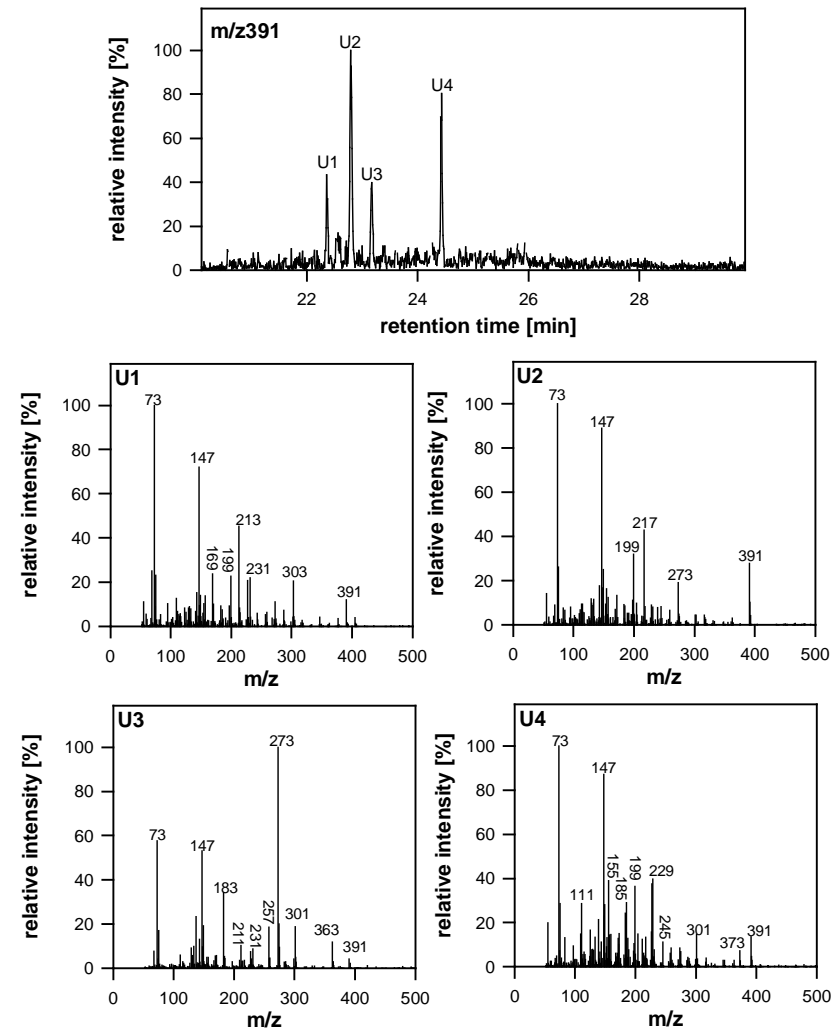

Fig. 10. GC-MS chromatogram of selected ion $\mathrm{m} / z 391 \mathrm{de}-$ noting trimeethylsilyl derivatives of $\mathrm{C}_{7}$-tricarboxylic acid or $\mathrm{C}_{8}$ hydroxydicarboxylic acid unidentified compounds (U1, U2, U3 and U4) in ambient $\mathrm{PM}_{2.5}$. The four unidentified isomers elute between 22 and $25 \mathrm{~min}$, within the retention time range of terpene SOC multifunctional markers. The ion at $\mathrm{m} / \mathrm{z} 391$ corresponds to the $\left[\mathrm{M}-\mathrm{CH}_{3}\right]^{+}$fragment, indicating a molecular weight of $406 \mathrm{~g} \mathrm{~mol}^{-1}$ for trimethylsilylated compounds and a molecular weight of $190 \mathrm{~g} \mathrm{~mol}^{-1}$ for underivatized compounds bearing three hydroxylic groups. The 4 isomers exhibit an EI/MS fragmentation pattern similar to the multifunctional compounds reported in Table 1 . 


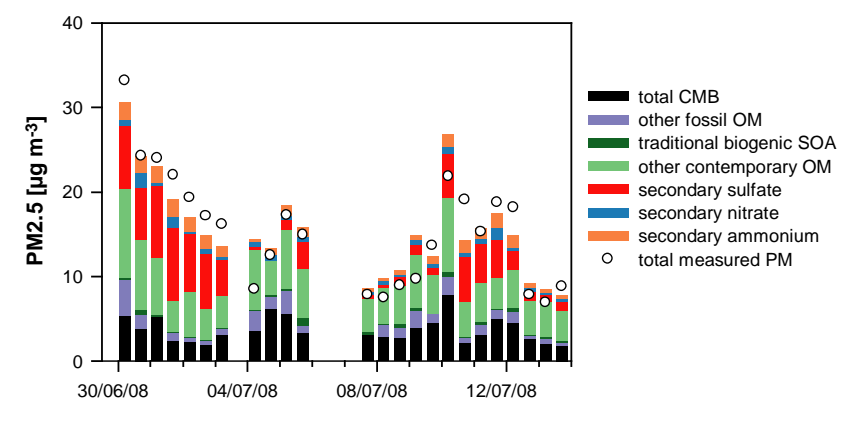

Fig. 11. Source contributions to fine particulate matter $\left(\mathrm{PM}_{2.5}\right)$ as estimated by CMB modelling, SOA marker approach and radiocarbon measurements. Also shown are the concentrations of $\mathrm{PM}_{2.5}$ measured by TEOM-FDMS (white circles).

$n=24$, Fig. 9), indicating that processes leading to these compounds are deeply involved in the formation of this fraction, thus confirming the tentative attribution of Baduel (2010). In the latter study, HULIS ${ }_{\mathrm{ws}}$ showed very good correlations with oxalic and glutaric acids in various French cities (Marseille, Toulous and Grenoble) in summertime (Baduel, 2010). Sources of glutaric and oxalic acids are not very well established in urban environments, nevertheless it is thought to be mainly secondary (Legrand et al., 2007).

The average concentration of HULIS ${ }_{W S}$ is $0.65 \mu \mathrm{g} \mathrm{m}^{-3}$, accounting on average for $14.4 \%$ of the total OC or $19.5 \%$ of other-SOC. It should be noted that HULIS ${ }_{\mathrm{WS}}$ measured here denotes the water-soluble HULIS only while organic aerosol generally comprises equal amounts of water insoluble (or alkaline soluble) HULIS (Baduel et al., 2009; Feczko et al., 2007). Under this assumption, total HULIS (HULIS $_{T}$ ) would account for $\sim 30 \%$ of total OC, explaining $\sim 40 \%$ of the other-SOC fraction.

\section{Source contributions to fine-particle mass}

Figure 11 displays the temporal trend for the source estimates of $\mathrm{PM}_{2.5}$ resulting from the integrated source apportionment approach used in this study. $\mathrm{PM}_{2.5}$ mass is attributed to basic source classes that include primary emissions assessed by the CMB model (El Haddad et al., 2011), secondary inorganic ions (nitrate, sulphate and ammonium) and SOA (apportioned by the CMB). The latter fraction is further subdivided into three subcategories that include traditional biogenic SOA, other contemporary OM (i.e., other contemporary/biogenic SOA) and other fossil OM (i.e., fossil SOA). Traditional biogenic SOA represents the aggregate contribution from SOA derived from isoprene, $\alpha$-pinene and $\beta$-caryophylene. These are computed by multiplying SOC mass derived from a given precursor by SOA-to-SOC ratio characteristic of this precursor, as reported in Kleindienst et al. (2007). Other contemporary and other fossil OM masses are inferred from $\mathrm{SOC}_{\mathrm{C}}$ and $\mathrm{SOC}_{\mathrm{F}}$, respectively, using an
OM-to-OC of 1.8 characteristic of the overall CMB-SOC fraction (for more information see El Haddad et al., 2011).

Our estimates for the aggregate contribution of $\mathrm{PM}_{2.5}$ primary sources range between $13 \%$ and $46 \%$ (average 26\%), falling towards the low end of the range of previous $\mathrm{CMB}$ modelling summertime studies performed in urban areas (Ke et al., 2007; Stone et al., 2008; Zheng et al., 2006). Consequently, ambient $\mathrm{PM}_{2.5}$ concentrations are largely governed by secondary species. The most striking feature is that total SOA constitutes the largest contributor. Within this fraction and according the $f_{\text {SOC }}$ approach, the traditional biogenic SOA provides only a small contribution, ranging between $0.32 \%$ and $5.6 \%$ (average $2 \%$ ) of the ambient $\mathrm{PM}_{2.5}$ mass. The other contemporary OM, most of which is SOA derived from biogenic emissions, accounts for between $17 \%$ and $44 \%$ (average $30 \%$ ) of the ambient $\mathrm{PM}_{2.5}$ mass. The other fossil OM, most of which is anthropogenic SOA, represents between 5.6\% and $21 \%$ (average 11\%) of the ambient $\mathrm{PM}_{2.5}$ mass. The aggregate contributions from inorganic ions, dominated by sulphates, represent between $9 \%$ and $62 \%$ (average $31 \%$ ) of the ambient $\mathrm{PM}_{2.5}$ mass. These results contribute to the growing body of evidence that the secondary fraction of the aerosol governs the ambient $\mathrm{PM}_{2.5}$ concentrations. This fraction is largely dominated by biogenic SOA, even if the aerosol is impacted by anthropogenic emissions. The larger part of this fraction cannot be attributed to SOA derived from photo-oxidation of traditional biogenic precursors, underlining significant contributions from other formation pathways (i.e. aging, polymerisation, photo-oxidation of other precursors...) to SOA emissions.

\section{Outlooks}

In the light of the results discussed in this paper, several issues remain unanswered and have to be validated in further studies. Further long-term measurements are needed to confirm the trends of biogenic SOC markers observed in this study and their sensitivity towards meteorological conditions and ambient parameters $\left(\mathrm{NO}_{\mathrm{x}}\right.$, aerosol acidity ...). Furthermore, it is suggested that the markers used here can undergo further reactions, potentially giving rise to $\mathrm{RSO}_{4} \mathrm{H}$ or HULIS, which may explain their depletion. In this respect, it would be worthwhile to determine with suitable analytical techniques the occurrence of $\mathrm{RSO}_{4} \mathrm{H}$ or other compounds that originate from the ambient SOC markers and the extent to which the formation of these compounds can affect the source apportionment. Further laboratory work is required to provide additional insights into the stability of SOC organic markers. Furthermore, chamber studies designed to determine marker profiles (i.e. marker-to-SOC ratios) have to span a wider range of experimental conditions $\left(\mathrm{NO}_{\mathrm{x}}\right.$, aerosol acidity, humidity, precursor initial concentration ...), which can allow assessment of the influence of these parameters on marker profiles. Finally, given the variability in ambient 
profiles of marker compounds, assessment of SOC using marker-based approaches must be addressed using more than an individual source profile, enabling to better capture varying conditions influencing SOC formation.

\section{Supplement related to this article is available online at: http://www.atmos-chem-phys.net/11/2059/2011/ acp-11-2059-2011-supplement.pdf.}

Acknowledgements. This work was funded by the Ministère de l'Ecologie, du Développement et de l'Aménagement Durable and by l'Agence gouvernementale De l'Environnement et de la Maîtrise de l'Energie (ADEME) under the PRIMEQUAL2 grant no. 0001135 (FORMES program). Additionnal fundings come from the Centre National de la Recherche Scientifique (CNRS) and the Institut National des Sciences de l'Univers (INSU). Accelerator Mass Spectrometry dating was provided by UMS-ARTEMIS (Saclay, France), with a Grant from the ARTEMIS program (INSU-CNRS). I. El Haddad gratefully acknowledges Dr. Tadeusz E. Kleindienst (National Exposure Research Laboratory, US-EPA, Research Triangle Park, North Carolina, USA) for the informative discussions.

Edited by: L. M. Russell

\section{References}

Alfarra, M. R., Paulsen, D., Gysel, M., Garforth, A. A., Dommen, J., Prevot, A. S. H., Worsnop, D. R., Baltensperger, U., and Coe, H.: A mass spectrometric study of secondary organic aerosols formed from the photooxidation of anthropogenic and biogenic precursors in a reaction chamber, Atmos. Chem. Phys., 6, 52795293, doi:10.5194/acp-6-5279-2006, 2006.

Baduel, C., Voisin, D., and Jaffrezo, J. L.: Comparison of analytical methods for HULIS measurements in atmospheric particles, Atmos. Chem. Phys. Discuss., 9, 6787-6825, doi:10.5194/acp9-6787-2009, 2009.

Baduel, C.: Fraction organique de l'aerosol : quantification et caractérisation de la fraction Humic LIke, PhD thesis, Université Joseph Fourier, Grenoble, http://tel.archives-ouvertes.fr/ tel-00467070, 2010.

Baduel, C., Voisin, D., and Jaffrezo, J. L.: Seasonal variations of concentrations and optical properties of water soluble HULIS collected in urban environments, Atmos. Chem. Phys., 10, 40854095, doi:10.5194/acp-10-4085-2010, 2010.

Bench, G.: Measurement of contemporary and fossil carbon contents of $\mathrm{PM}_{2.5}$ aerosols: Results from Turtleback Dome, Yosemite National Park, Environ. Sci. Technol., 38, 2424-2427, 2004.

Birch, M. E., and Cary, R. A.: Elemental carbon-based method for monitoring occupational exposures to particulate diesel exhaust, Environ. Sci. Technol., 25, 221-241, 1996.

Camredon, M., Hamilton, J. F., Alam, M. S., Wyche, K. P., Carr, T., White, I. R., Monks, P. S., Rickard, A. R., and Bloss, W. J.: Distribution of gaseous and particulate organic composition during dark \&alpha; -pinene ozonolysis, Atmos. Chem. Phys., 10, 2893-2917, doi:10.5194/acp-10-2893-2010, 2010.
Carlton, A. G., Wiedinmyer, C., and Kroll, J. H.: A review of Secondary Organic Aerosol (SOA) formation from isoprene, Atmos. Chem. Phys., 9, 4987-5005, doi:10.5194/acp-9-4987-2009, 2009.

Claeys, M., Graham, B., Vas, G., Wang, W., Vermeylen, R., Pashynska, V., Cafmeyer, J., Guyon, P., Andreae, M. O., Artaxo, P., and Maenhaut, W.: Formation of secondary organic aerosols through photooxidation of isoprene, Science, 303, 1173-1176, 2004a.

Claeys, M., Wang, W., Ion, A. C., Kourtchev, I., Gelencser, A., and Maenhaut, W.: Formation of secondary organic aerosols from isoprene and its gas-phase oxidation products through reaction with hydrogen peroxide, Atmos. Environ., 38, 4093-4098, 2004b.

Claeys, M., Szmigielski, R., Kourtchev, I., Van der Veken, P., Vermeylen, R., Maenhaut, W., Jaoui, M., Kleindienst, T. E., Lewandowski, M., Offenberg, J. H., and Edney, E. O.: Hydroxydicarboxylic acids: Markers for secondary organic aerosol from the photooxidation of alpha-pinene, Environ. Sci. Technol., 41, 1628-1634, 2007.

de Gouw, J. and Warneke, C.: Measurements of volatile organic compounds in the earth's atmosphere using proton-transferreaction mass spectrometry, Mass Spectrom. Rev., 26, 223-257, 2007.

de Gouw, J. A., Goldan, P. D., Warneke, C., Kuster, W. C., Roberts, J. M., Marchewka, M., Bertman, S. B., Pszenny, A. A. P., and Keene, W. C.: Validation of proton transfer reaction-mass spectrometry (PTR-MS) measurements of gas-phase organic compounds in the atmosphere during the New England Air Quality Study (NEAQS) in 2002, J. Geophys. Res.-Atmos., 108, 4682, doi:10.1029/2003JD003863, 2003.

Ding, X., Zheng, M., Yu, L. P., Zhang, X. L., Weber, R. J., Yan, B., Russell, A. G., Edgerton, E. S., and Wang, X. M.: Spatial and seasonal trends in biogenic secondary organic aerosol tracers and water-soluble organic carbon in the southeastern United States, Environ. Sci. Technol., 42, 5171-5176, 2008.

Donahue, N. M., Robinson, A. L., Stanier, C. O., and Pandis, S. N.: Coupled partitioning, dilution, and chemical aging of semivolatile organics, Environ. Sci. Technol., 40, 2635-2643, doi:10.1021/esO52297c, 2006.

Dron, J., Eyglunent, G., Temime-Roussel, B., Marchand, N., and Wortham, H.: Carboxylic acid functional group analysis using constant neutral loss scanning-mass spectrometry, Analytica Chimica Acta, 605, 61-69, 2007.

Dron, J., Zheng, W., Marchand, N., and Wortham, H.: New method to determine the total carbonyl functional group content in extractable particulate organic matter by tandem mass spectrometry, J. Mass Spectrom., J. Mass Spectrom., 43, 1089-1098, doi:10.1002/jms.1392, 2008a.

Dron, J., Abidi, E., El Haddad, I., Marchand, N., and Wortham, H.: Precursor ion scanning-mass spectrometry for the determination of nitro functional groups in atmospheric particulate organic matter, Analytica Chimica Acta, 618, 184-195, 2008b.

El Haddad, I., Marchand, N., Wortham, H., Piot, C., Besombes, J.-L., Cosic, J., Chauvel, C., Armengaud, A., Robin, D., and Jaffrezo, J.-L.: Primary sources of $\mathrm{PM}_{2.5}$ organic aerosol in an industrial Mediterranean city, Marseille, Atmos. Chem. Phys., 11, 2039-2058, doi:10.5194/acp-11-2039-2011, 2011.

Feczko, T., Puxbaum, H., Kasper-Giebl, A., Handler, M., Limbeck, A., Gelencser, A., Pio, C., Preunkert, S., and Legrand, M.: De- 
termination of water and alkaline extractable atmospheric humiclike substances with the TU Vienna HULIS analyzer in samples from six background sites in Europe, J. Geophys. Res.-Atmos., 112, D23S10, doi:10.1029/2006JD008331, 2007.

Gelencser, A., May, B., Simpson, D., Sanchez-Ochoa, A., KasperGiebl, A., Puxbaum, H., Caseiro, A., Pio, C., and Legrand, M.: Source apportionment of $\mathrm{PM}_{2.5}$ organic aerosol over Europe: Primary/secondary, natural/anthropogenic, and fossil/biogenic origin, J. Geophys. Res.-Atmos., 112, D23S04, doi:10.1029/2006JD008094, 2007.

Goldstein, A. H. and Galbally, I. E.: Known and unexplored organic constituents in the earth's atmosphere, Environ. Sci. Technol., 41, 1514-1521, 2007.

Grieshop, A. P., Donahue, N. M., and Robinson, A. L.: Laboratory investigation of photochemical oxidation of organic aerosol from wood fires 2: analysis of aerosol mass spectrometer data, Atmos. Chem. Phys., 9, 2227-2240, doi:10.5194/acp-9-2227-2009, 2009a.

Grieshop, A. P., Logue, J. M., Donahue, N. M., and Robinson, A. L.: Laboratory investigation of photochemical oxidation of organic aerosol from wood fires 1: measurement and simulation of organic aerosol evolution, Atmos. Chem. Phys., 9, 1263-1277, doi:10.5194/acp-9-1263-2009, 2009b.

Hallquist, M., Wenger, J. C., Baltensperger, U., Rudich, Y., Simpson, D., Claeys, M., Dommen, J., Donahue, N. M., George, C., Goldstein, A. H., Hamilton, J. F., Herrmann, H., Hoffmann, T., Iinuma, Y., Jang, M., Jenkin, M. E., Jimenez, J. L., KiendlerScharr, A., Maenhaut, W., McFiggans, G., Mentel, T. F., Monod, A., Prevot, A. S. H., Seinfeld, J. H., Surratt, J. D., Szmigielski, R., and Wildt, J.: The formation, properties and impact of secondary organic aerosol: current and emerging issues, Atmos. Chem. Phys., 9, 5155-5236, doi:10.5194/acp-9-5155-2009, 2009.

Hamilton, J. F., Webb, P. J., Lewis, A. C., Hopkins, J. R., Smith, S., and Davy, P.: Partially oxidised organic components in urban aerosol using GCXGC-TOF/MS, Atmos. Chem. Phys., 4, 12791290, doi:10.5194/acp-4-1279-2004, 2004.

Heald, C. L., Jacob, D. J., Park, R. J., Russell, L. M., Huebert, B. J., Seinfeld, J. H., Liao, H., and Weber, R. J.: A large organic aerosol source in the free troposphere missing from current models, Geophys. Res. Lett., 32, 2005.

Hildebrandt, L., G. J. Engelhart, C. Mohr, E. Kostenidou, V. A. Lanz, A. Bougiatioti, P. F. DeCarlo, A. S. H. Prevot, U. Baltensperger, N. Mihalopoulos, N. M. Donahue, and S. N. Pandis: Aged organic aerosol in the Eastern Mediterranean: the Finokalia Aerosol Measurement Experiment-2008, Atmos. Chem. Phys., 10, 4167-4186, doi:10.5194/acp-10-4167-2010, 2010.

Hodzic, A., Jimenez, J. L., Prévôt, A. S. H., Szidat, S., Fast, J. D., and Madronich, S.: Can 3-D models explain the observed fractions of fossil and non-fossil carbon in and near Mexico City?, Atmos. Chem. Phys., 10, 10997-11016, doi:10.5194/acp10-10997-2010, 2010.

Ion, A. C., Vermeylen, R., Kourtchev, I., Cafmeyer, J., Chi, X., Gelencser, A., Maenhaut, W., and Claeys, M.: Polar organic compounds in rural $\mathrm{PM}_{2.5}$ aerosols from K-puszta, Hungary, during a 2003 summer field campaign: Sources and diel variations, Atmos. Chem. Phys., 5, 1805-1814, doi:10.5194/acp-5-1805-2005, 2005.

Jaffrezo, J.-L., Aymoz, G., Delaval, C., and Cozic, J.: Seasonal variations of the water soluble organic carbon mass fraction of aerosol in two valleys of the French Alps, Atmos. Chem. Phys. 5, 2809-2821, doi:10.5194/acp-5-2809-2005, 2005.

Jaffrezo, J. L., Calas, T., and Bouchet, M.: Carboxylic acids measurements with ionic chromatography, Atmos. Environ., 32, 2705-2708, 1998.

Jaoui, M., Kleindienst, T. E., Lewandowski, M., Offenberg, J. H., and Edney, E. O.: Identification and quantification of aerosol polar oxygenated compounds bearing carboxylic or hydroxyl groups. 2. Organic tracer compounds from monoterpenes, Environ. Sci. Technol., 39, 5661-5673, 2005.

Jaoui, M., Corse, E., Kleindienst, T. E., Offenberg, J. H., Lewandowski, M., and Edney, E. O.: Analysis of secondary organic aerosol compounds from the photooxidation of d-limonene in the presence of NOX and their detection in ambient $\mathrm{PM}_{2.5}$, Environ. Sci. Technol., 40, 3819-3828, 2006.

Jaoui, M., Lewandowski, M., Kleindienst, T. E., Offenberg, J. H., and Edney, E. O.: beta-caryophyllinic acid: An atmospheric tracer for beta-caryophyllene secondary organic aerosol, Geophys. Res. Lett., 34, 2007.

Jimenez, J. L., Canagaratna, M. R., Donahue, N. M., Prevot, A. S. H., Zhang, Q., Kroll, J. H., DeCarlo, P. F., Allan, J. D., Coe, H., Ng, N. L., Aiken, A. C., Docherty, K. S., Ulbrich, I. M., Grieshop, A. P., Robinson, A. L., Duplissy, J., Smith, J. D., Wilson, K. R., Lanz, V. A., Hueglin, C., Sun, Y. L., Tian, J., Laaksonen, A., Raatikainen, T., Rautiainen, J., Vaattovaara, P., Ehn, M., Kulmala, M., Tomlinson, J. M., Collins, D. R., Cubison, M. J., Dunlea, E. J., Huffman, J. A., Onasch, T. B., Alfarra, M. R., Williams, P. I., Bower, K., Kondo, Y., Schneider, J., Drewnick, F., Borrmann, S., Weimer, S., Demerjian, K., Salcedo, D., Cottrell, L., Griffin, R., Takami, A., Miyoshi, T., Hatakeyama, S., Shimono, A., Sun, J. Y., Zhang, Y. M., Dzepina, K., Kimmel, J. R., Sueper, D., Jayne, J. T., Herndon, S. C., Trimborn, A. M., Williams, L. R., Wood, E. C., Middlebrook, A. M., Kolb, C. E., Baltensperger, U., and Worsnop, D. R.: Evolution of organic aerosols in the atmosphere, Science, 326, 1525-1529, 2009.

Kanakidou, M., Seinfeld, J. H., Pandis, S. N., Barnes, I., Dentener, F. J., Facchini, M. C., Van Dingenen, R., Ervens, B. N., A.; , Nielsen, C. J., Swietlicki, E., Putaud, J. P., Balkanski, Y., Fuzzi, S., Horth, J., Moortgat, G. K., Winterhalter, R., Myhre, C. E. L., Tsigaridis, K., Vignati, E., Stephanou, E. G., and Wilson, J.: Organic aerosol and global climate modelling: A review, Atmos. Chem. Phys. 5, 1053-1123, doi:10.5194/acp-5-1053-2005, 2005.

Ke, L., Ding, X., Tanner, R. L., Schauer, J. J., and Zheng, M.: Source contributions to carbonaceous aerosols in the Tennessee Valley Region, Atmos. Environ., 41, 8898-8923, 2007.

Kessler, S. H., Smith, J. D., Che, D. L., Worsnop, D. R., Wilson, K. R., and Kroll, J. H.: Chemical sinks of organic aerosol: kinetics and products of the heterogeneous oxidation of erythritol and levoglucosan, Environ. Sci. Technol., 44, 7005-7010, 2010.

Kleindienst, T. E., Jaoui, M., Lewandowski, M., Offenberg, J. H., Lewis, C. W., Bhave, P. V., and Edney, E. O.: Estimates of the contributions of biogenic and anthropogenic hydrocarbons to secondary organic aerosol at a southeastern US location, Atmos. Environ., 41, 8288-8300, 2007.

Kleindienst, T. E., Lewandowski, M., Offenberg, J. H., Jaoui, M., and Edney, E. O.: The formation of secondary organic aerosol from the isoprene plus $\mathrm{OH}$ reaction in the absence of NOx, At- 
mos. Chem. Phys., 9, 6541-6558, doi:10.5194/acp-9-6541-2009, 2009.

Kourtchev, I., Warnke, J., Maenhaut, W., Hoffmann, T., and Claeys, M.: Polar organic marker compounds in $\mathrm{PM}_{2.5}$ aerosol from a mixed forest site in western Germany, Chemosphere, 73, 13081314, 2008.

Kourtchev, I., Copolovici, L., Claeys, M., and Maenhaut, W.: Characterization of atmospheric aerosols at a forested site in central europe, Environ. Sci. Technol., 43, 4665-4671, 2009.

Kroll, J. H., Ng, N. L., Murphy, S. M., Flagan, R. C., and Seinfeld, J. H.: Secondary organic aerosol formation from isoprene photooxidation under high-NOx conditions, Geophys. Res. Lett., 32, L18808, doi:10.1029/2005GL023637, 2005.

Kroll, J. H., Ng, N. L., Murphy, S. M., Flagan, R. C., and Seinfeld, J. H.: Secondary organic aerosol formation from isoprene photooxidation, Environ. Sci. Technol., 40, 1869-1877, 2006.

Kuster, W. C., Jobson, B. T., Karl, T., Riemer, D., Apel, E., Goldan, P. D., and Fehsenfeld, F. C.: Intercomparison of volatile organic carbon measurement techniques and data at la porte during the TexAQS2000 Air Quality Study, Environ. Sci. Technol., 38, 221228, 2004.

Lang-Yona, N., Rudich, Y., Mentel, Th. F., Bohne, A., Buchholz, A., Kiendler-Scharr, A., Kleist, E., Spindler, C., Tillmann, R., and Wildt, J.: The chemical and microphysical properties of secondary organic aerosols from Holm Oak emissions, Atmos. Chem. Phys., 10, 7253-7265, doi:10.5194/acp-10-7253-2010, 2010.

Legrand, M., Preunkert, S., Oliveira, T., Pio, C. A., Hammer, S., Gelencser, A., Kasper-Giebl, A., and Laj, P.: Origin of C-2-C-5 dicarboxylic acids in the European atmosphere inferred from year-round aerosol study conducted at a west10.1029/2006jd008019east transect, J. Geophys. Res.-Atmos., 112, D23S07, doi:10.1029/2006JD008019, 2007.

Levin, I., Kromer, B., Schochfischer, H., Bruns, M., Munnich, M., Berdau, D., Vogel, J. C., and Munnich, K. O.: 25 years of tropospheric C-14 observations in central-Europe, Radiocarbon, 27, 1-19, 1985.

Levin, I., and Hesshaimer, V.: Radiocarbon - A unique tracer of global carbon cycle dynamics, Radiocarbon, 42, 69-80, 2000.

Lewandowski, M., Jaoui, M., Offenberg, J. H., Kleindienst, T. E., Edney, E. O., Sheesley, R. J., and Schauer, J. J.: Primary and secondary contributions to ambient PM in the midwestern United States, Environ. Sci. Technol., 42, 3303-3309, 2008.

Lindinger, W., Hansel, A., and Jordan, A.: On-line monitoring of volatile organic compounds at pptv levels by means of protontransfer-reaction mass spectrometry (PTR-MS) - Medical applications, food control and environmental research, International J. Mass Spectrom., 173, 191-241, 1998.

Montzka, S. A., Trainer, M., Goldan, P. D., Kuster, W. C., and Fehsenfeld, F. C.: Isoprene and Its oxidation-products, methyl vinyl ketone and methacrolein, in the rural troposphere, J. Geophys. Res.-Atmos., 98, 1101-1111, 1993.

Ng, N. L., Kroll, J. H., Keywood, M. D., Bahreini, R., Varutbangkul, V., Flagan, R. C., Seinfeld, J. H., Lee, A., and Goldstein, A. H.: Contribution of first- versus second-generation products to secondary organic aerosols formed in the oxidation of biogenic hydrocarbons, Environ. Sci. Technol., 40, 2283-2297, 2006.

Owen, S. M., Harley, P., Guenther, A., and Hewitt, C. N.: Light de- pendency of VOC emissions from selected Mediterranean plant species, Atmos. Environ., 36, 3147-3159, 2002.

Parra, R., Gasso, S., and Baldasano, J. M.: Estimating the biogenic emissions of non-methane volatile organic compounds from the North Western Mediterranean vegetation of Catalonia, Spain, Sci. Total Environ., 329, 241-259, 2004.

Paulot, F., Crounse, J. D., Kjaergaard, H. G., Kurten, A., St Clair, J. M., Seinfeld, J. H., and Wennberg, P. O.: Unexpected epoxide formation in the gas-phase photooxidation of isoprene, Science, 325, 730-733, 2009.

Robinson, A. L., Donahue, N. M., Shrivastava, M. K., Weitkamp, E. A., Sage, A. M., Grieshop, A. P., Lane, T. E., Pierce, J. R., and Pandis, S. N.: Rethinking organic aerosols: Semivolatile emissions and photochemical aging, Science, 315, 1259-1262, doi:10.1126/science.1133061, 2007.

Rontani, J. F. and Aubert, C.: Trimethylsilyl transfer during electron ionization mass spectral fragmentation of some omegahydroxycarboxylic and omega-dicarboxylic acid trimethylsilyl derivatives and the effect of chain length, Rapid Comm. Mass Spectrom., 18, 1889-1895, 2004.

Russell, L. M., Hawkins, L. N., Frossard A. A., Quinn, P. K., and Bates, T. S.: Carbohydrate-like composition of submicron atmospheric particles and their production from ocean bubble bursting, PNAS, 107, 6652-6657, 2010.

Sage, A. M., Weitkamp, E. A., Robinson, A. L., and Donahue, N. M.: Evolving mass spectra of the oxidized component of organic aerosol: results from aerosol mass spectrometer analyses of aged diesel emissions, Atmos. Chem. Phys., 8, 1139-1152, doi:10.5194/acp-8-1139-2008, 2008.

Schauer, J. J., Rogge, W. F., Hildemann, L. M., Mazurek, M. A., Cass, G. R., and Simoneit, B. R. T.: Source apportionment of airborne particulate matter using organic compounds as tracers, Atmos. Environ., 30, 3837-3855, 1996.

Schauer, J. J. and Cass, G. R.: Source apportionment of wintertime gas-phase and particle-phase air pollutants using organic compounds as tracers. Environ. Sci. Technol., 34, 1821-1832, 2000.

Schauer, J. J., Fraser, M. P., Cass, G. R., and Simoneit, B. R. T.: Source reconciliation of atmospheric gas-phase and particlephase pollutants during a severe photochemical smog episode, Environ. Sci. Technol. 36, 3806-3814, 2002.

Schmid, H., Laskus, L., Jürgen Abraham, H., Baltensperger, U., Lavanchy, V., Bizjak, M., Burba, P., Cachier, H., Crow, D., Chow, J., Gnauk, T., Even, A., ten Brink, H. M., Giesen, K.-P., Hitzenberger, R., Hueglin, C., Maenhaut, W., Pio, C., Carvalho, A., Putaud, J.-P., Toom-Sauntry, D., and Puxbaum, H.: Results of the "carbon conference" international aerosol carbon round robin test stage I, Atmos. Environ., 35, 2111-2121, 2001.

Simon, V., Dumergues, L., Ponche, J. L., and Torres, L.: The biogenic volatile organic compounds emission inventory in France - Application to plant ecosystems in the Berre-Marseilles area (France), Sci. Total Environ., 372, 164-182, 2006.

Steinbrecher, R., Smiatek, G., Koble, R., Seufert, G., Theloke, J., Hauff, K., Ciccioli, P., Vautard, R., and Curci, G.: Intra- and inter-annual variability of VOC emissions from natural and seminatural vegetation in Europe and neighbouring countries, Atmos. Environ., 43, 1380-1391, 2009.

Stone, E. A., Snyder, D. C., Sheesley, R. J., Sullivan, A. P., Weber, R. J., and Schauer, J. J.: Source apportionment of fine organic aerosol in Mexico City during the MILAGRO experiment 
2006, Atmos. Chem. Phys., 8, 1249-1259, doi:10.5194/acp-81249-2008, 2008.

Stone, E. A., Zhou, J. B., Snyder, D. C., Rutter, A. P., Mieritz, M., and Schauer, J. J.: A Comparison of summertime secondary organic aerosol source contributions at contrasting urban locations, Environ. Sci. Technol., 43, 3448-3454, 2009.

Surratt, J. D., Murphy, S. M., Kroll, J. H., Ng, N. L., Hildebrandt, L., Sorooshian, A., Szmigielski, R., Vermeylen, R., Maenhaut, W., Claeys, M., Flagan, R. C., and Seinfeld, J. H.: Chemical composition of secondary organic aerosol formed from the photooxidation of isoprene, J. Phys. Chem. A, 110, 9665-9690, 2006.

Surratt, J. D., Lewandowski, M., Offenberg, J. H., Jaoui, M., Kleindienst, T. E., Edney, E. O., and Seinfeld, J. H.: Effect of acidity on secondary organic aerosol formation from isoprene, Environ. Sci. Technol., 41, 5363-5369, 2007.

Surratt, J. D., Gomez-Gonzalez, Y., Chan, A. W. H., Vermeylen, R., Shahgholi, M., Kleindienst, T. E., Edney, E. O., Offenberg, J. H., Lewandowski, M., Jaoui, M., Maenhaut, W., Claeys, M., Flagan, R. C., and Seinfeld, J. H.: Organosulfate formation in biogenic secondary organic aerosol, J. Phys. Chem. A, 112, 8345-8378, 2008.

Szmigielski, R., Surratt, J. D., Gomez-Gonzalez, Y., Van der Veken, P., Kourtchev, I., Vermeylen, R., Blockhuys, F., Jaoui, M., Kleindienst, T. E., Lewandowski, M., Offenberg, J. H., Edney, E. O., Seinfeld, J. H., Maenhaut, W., and Claeys, M.: 3-methyl1,2,3-butanetricarboxylic acid: An atmospheric tracer for terpene secondary organic aerosol, Geophys. Res. Lett., 34, L24811, doi:10.1029/2007GL031338, 2007.
Tanner, R. L., Parkhurst, W. J., and McNichol, A. P.: Fossil sources of ambient aerosol carbon based on C-14 measurements, Aerosol Sci. Technol., 38, 133-139, 2004.

Volkamer, R., Jimenez, J. L., San Martini, F., Dzepina, K., Zhang, Q., Salcedo, D., Molina, L. T., Worsnop, D. R., and Molina, M. J.: Secondary organic aerosol formation from anthropogenic air pollution: Rapid and higher than expected, Geophys. Res. Lett., 33, L17811, doi:10.1029/2006GL026899, 2006.

Watson, J. G., Robinson, N. F., Fujita, E. M., Chow, J. C., Pace, T. G., Lewis, C., and Coulter, T.: CMB8 Applications and Validation Protocol for $\mathrm{PM}_{2.5}$ and VOCs, US EPA, USA, 1998.

Zhao, J., and Zhang, R. Y.: Proton transfer reaction rate constants between hydronium ion $(\mathrm{H} 3 \mathrm{O}(+))$ and volatile organic compounds, Atmos. Environ., 38, 2177-2185, 2004.

Zheng, M., Ke, L., Edgerton, E. S., Schauer, J. J., Dong, M. Y., and Russell, A. G.: Spatial distribution of carbonaceous aerosol in the southeastern United States using molecular markers and carbon isotope data, J. Geophys. Res.-Atmos., 111, D10S06, doi:10.1029/2005JD006777, 2006. 